\title{
4. Abandoned agricultural lands in buffer zones around landscape parks in the Łódź Voivodeship - habitat background, spatial distribution, scale of the phenomenon
}

\author{
4.1. Abandoned lands around landscape parks on the Pilica River \\ (Przedbórz Landscape Park, Sulejów Landscape Park, Spała Landscape Park)
}

Stanisław Krysiak

The 10-km wide buffers around the three protected areas on the Pilica River - Spała Landscape Park, Sulejów Landscape Park and Przedbórz Landscape Park, form one integrated zone, because the parks are located close to each other. According to the physicogeographical division by J. Kondracki (2002), this area lies within the subprovince of the Central Polish Lowland (318) and the Lesser Poland Upland (342). The mesoregions which represent the Central Polish Lowland include: the Piotrków Plain (318.84), the Białobrzegi Valley (318.85), the Rawa Plateau (318.83), the Radom Plain (318.86) and small fragments of the Bełchatów Plateau (318.81) and the Łódź Hills (318.82). The southern part of the buffer zone around the Pilica parks, which lies in the subprovince of the Lesser Poland Upland, includes fragments of the following mesoregions: the Radomsko Hills (342.11), the Opoczno Hills (342.12), the Przedbórz-Małogoszcz Range (342.15), the Łopuszno Hills (342.16) and the Włoszczowa Basin (342.14) (Fig. 4.1). The analysed area encompassed $1232.79 \mathrm{~km}^{2}$.

A characteristic feature of the landscape of the $10-\mathrm{km}$ wide buffer zone around the Pilica parks is the merging of lowland and upland landscape elements. This is expressed in the coexistence of marine, glacial, fluvioglacial, fluvial, limnic, aeolian and biogenic deposits of different ages. The resulting petrographic diversity of surface deposits is reflected in the habitat potentials which predispose different fragments of the analysed area for specific forms of usage. The spatial structure of the analysed areas on the Pilica River is illustrated in the map of partial geocomplexes - morpholithohydrotopes (Fig. 4.2).
The share of areas taken by individual types of geocomplexes reflects the high amount of habitats with low resource potential, characteristic for areas in the vicinity of the Pilica river valley, related to the occurrence of excessively permeable Quaternary and Mesozoic formations (Fig. 4.2 and 4.3). They include extensive patches of fluvioglacial and glacial sands and gravels (geocomplex type 6), fluvial sands, gravels and muds of terraces and flood plains which accompany the Pilica River and its tributaries (types 8, 9 and 19), periglacial cover sands and silts of plateaus (type 20), aeolian sands of dunes and shields (type 15), small, but very numerous geocomplexes of moraine hills and kames (type 4), deluvial sands, silts and muds in bottoms of dry valleys (type 7) and outcrops of sands and sandstones (type 1). The more fertile habitats, related to the occurrence of low-permeable sediments, both Quaternary and Mesozoic, are represented by six geocomplex types. Of them the highest share is held by geocomplex type 5 - glacial tills of plateaus (36.6\%). Morpholithohydrotopes of type 16 and 18, in which the tills underlie permeable sediments, have a lower share $(4.5 \%$ and $5.9 \%$, respectively).

The spatial image of abandoned land distribution and abandonment intensity around landscape parks on the Pilica River was presented in Figure 4.4. The analysed area is dominated by agricultural lands, in which no abandoned lands were identified $(59.3 \%$ of the area). The percentage of areas included in each of five classes of abandonment intensity is illustrated with Figure 4.5. 


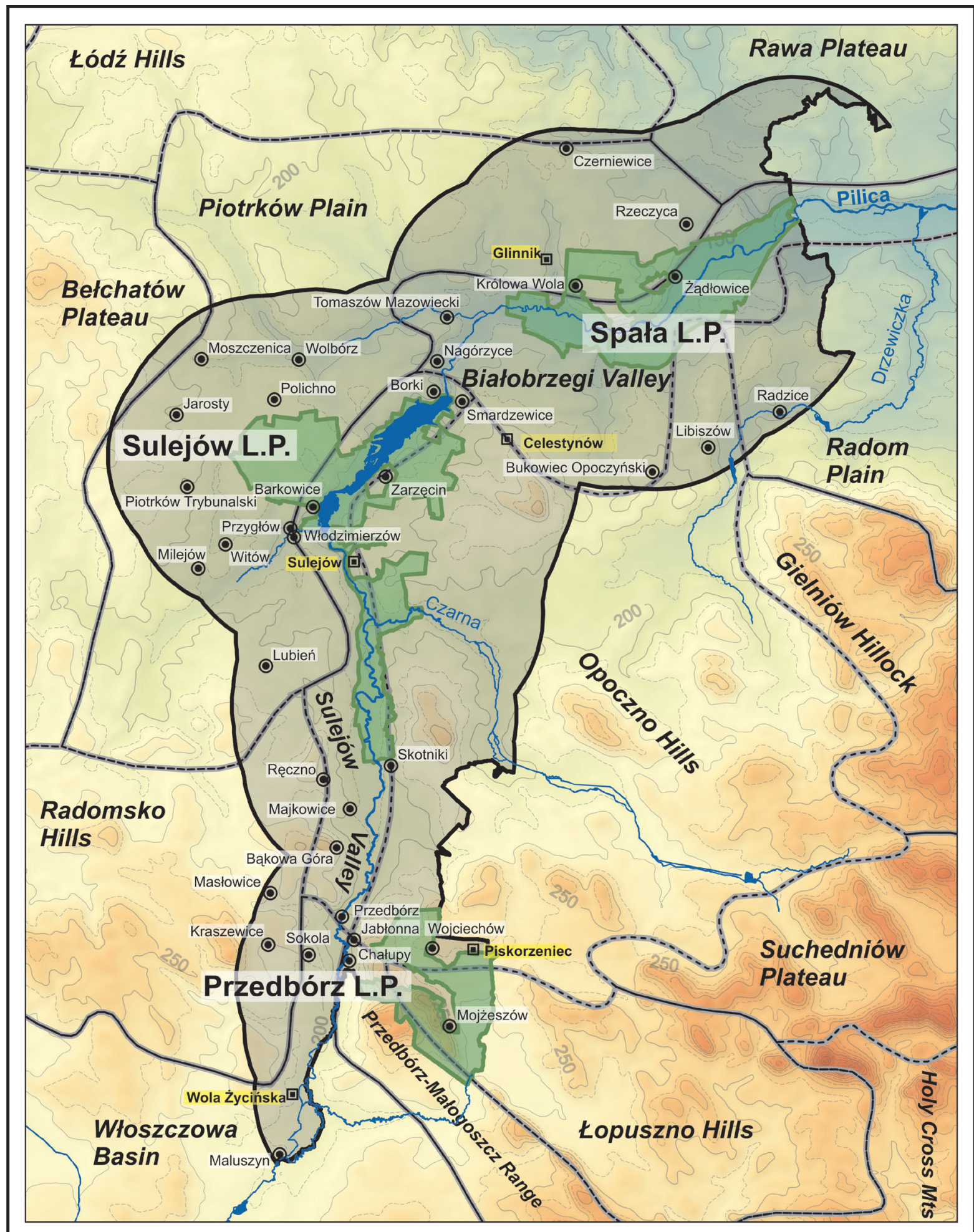

$\begin{array}{lllll}5 & 0 & 5 & 10 & 15 \mathrm{~km}\end{array}$

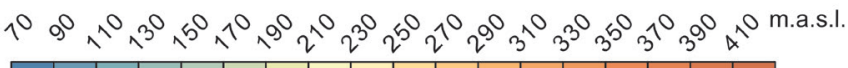

口 Wola Życińska $1 \bigcirc 2$

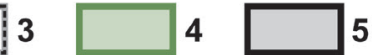

Fig. 4.1. Landscape parks on the Pilica River and their buffer zone, against the background of the physicogeographical units by J. Kondracki (2002)

1 - location of abandonment study plot groups; 2 - locations mentioned in the text; 3 - boundaries of physicogeographical units; 4 - landscape park areas; 5 - 10-km wide buffer zone around landscape parks

Source: own elaboration based on digital elevation model with grid interval of at least $100 \mathrm{~m}$ and other data made available by CODGiK (www.codgik.gov.pl) 


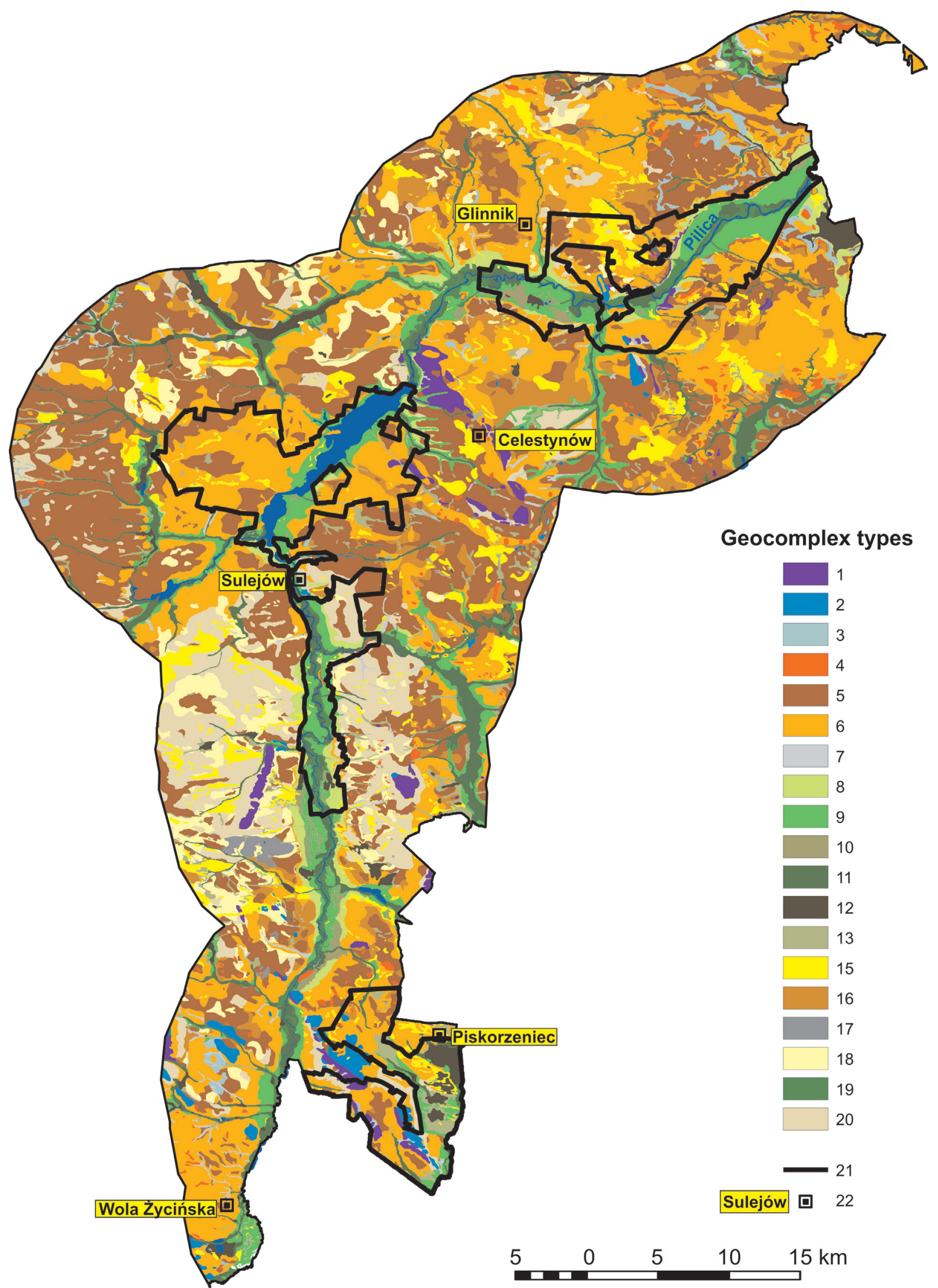

Fig. 4.2. Map of geocomplexes (morpholithohydrotopes) of the landscape parks on the Pilica River and their buffer zone

1-20 names of the morpholithohydrotopes are listed in Tab. 3.1; 21 - landscape park boundary; 22 - study plot group

Source: own elaboration 


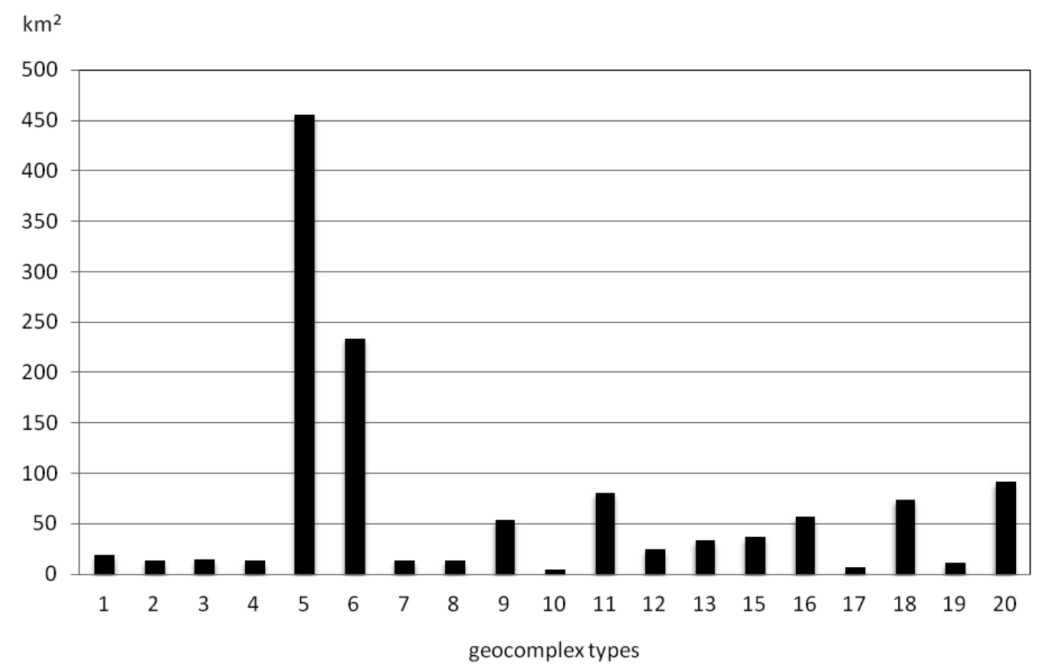

Fig. 4.3. The area of geocomplexes types in the structure of the natural environment of the buffer zone around landscape parks on the Pilica River

Source: own elaboration

The spatial layout of areas without abandoned lands (class 0 ) is related to areas with a high potential for biotic productivity. Class 0 areas cover vast fragments of the Piotrków Plain around Piotrków Trybunalski (the vicinities of Wolbórz, Polichno, Moszczenica, Jarosty, Przygłów, Witów, Milejów) and to the north of the Spała Landscape Park, in the area around Rzeczyca and Czerniewice. There are also no abandoned lands in some parts of the Radomsko Hills (the vicinities of Sokola Góra, Kraszewice, Masłowice, Bąkowa Góra, Majkowice, Ręczno) and the Opoczno Hills (the vicinities of Radzice, Libiszów, Bukowiec Opoczyński). Smaller areas without abandoned lands are also found in patches in other mesoregions around the Pilica landscape parks. In all cases, the lack of abandoned lands results from favourable agricultural conditions. Such conditions are mostly provided by places where the parent rocks are silts upon till (geocomplex type 17), glacial tills (type 5), clays, muds and mudstones (type 3 ) and other geocomplex types, where trophic and moisture conditions are shaped by the presence of glacial till in the lower part of the soil profile.

The occurrence of abandoned lands was found within the area of $502 \mathrm{~km}^{2}$. The most numerous are areas which belong to class 1 (up to $25 \%$ of abandoned lands), whose share exceeds $27 \%$.

Areas with a higher amount of abandoned lands (classes 2, 3 and 4) cover $13.4 \%$ in total. They usually form larger areas with an increased concentration of abandoned lands. These are exemplified by outcrops of sands and sandstones (type 1), gravels and sands of moraine and kame hills (type 4), glacial and fluvioglacial sands and gravels of plateaus (type 6), aeolian sands of dunes and shields (type 15). Such concentrations are often found near forest complexes, e.g. in the northern and western part of the Opoczno Hills, in the northern fragments of the Radomsko Hills, or between Lubień and Felicja in the southern part of the Piotrków Plain.

Fluvial sands, gravels and muds of the lower and upper terrace in the Pilica river valley (geocomplex types 8 and 9) are usually areas where soils are classified as very poor rye complex (7). Similar agricultural suitability is exhibited by light alluvial soils in the flood plain (type 19). This fact is well illustrated by a concentration of abandoned lands along the valley between Maluszyn and Skotniki (Fig. 4.4) and the share of abandoned lands in geocomplex types 10, 11 and 12 .

Areas of concentrated abandoned lands in the zone around the Pilica landscape parks also include grounds near urban settlement units.

Examples include areas around Tomaszów Mazowiecki, Piotrków Trybunalski, Sulejów and Przedbórz (Fig. 4.4).

A comparison between the map of land abandonment intensity (Fig. 4.4) and the map of geocomplexes (morpholithohydrotopes) (Fig. 4.2), conducted on the basis of output data from the ArcGIS software, made it possible to present in detail the percentage of abandonment intensity classes in different geocomplex types (Fig. 4.6). The results confirm the influence of the habitat potential of geocomplexes on the scale of the phenomenon of land abandonment. It is most well- 


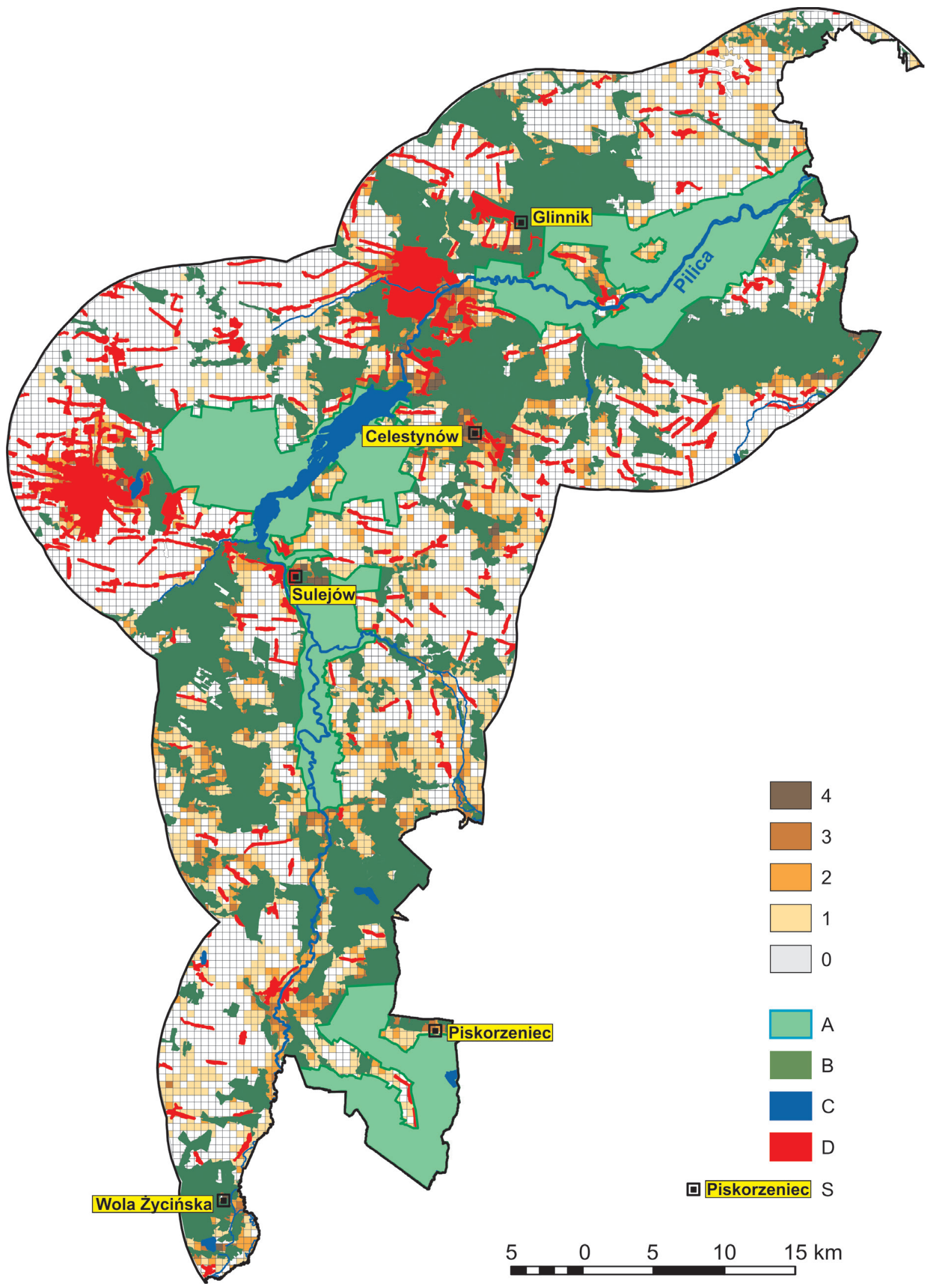

Fig. 4.4. Map of spatial distribution and intensity of land abandonment in the buffer zone around landscape parks on the Pilica River

A - landscape park areas; B - forest; C - water; D - artificial surfaces; S - study plot group

Farmland abandonment classes: 0 - no abandonment ( $0 \%$ area of basic square); 1 - low intensity (0.1 - 25\%);

2 - medium intensity (25.1 - 50\%); 3 - high intensity (50.1 - 75\%); 4 - very high intensity (75.1 - 100\%) 
-visible in the case of the most fertile geocomplex of type 17, built of silts upon glacial tills. It has the highest percentage of areas without abandoned lands and, at the same time, no lands in class 3 and 4 of abandonment intensity were found there. A similarly high share of areas without abandoned lands is recorded in plateaus built of glacial till (type 5), whose total area constitutes the basis for the development of agriculture on the Pilica
River. A computer analysis allowed to obtain information on the percentage share of areas of different geocomplex types in the land abandonment intensity classes (Tab. 4.1). Because $55.9 \%$ of the area of buffer zone around the Pilica landscape parks belongs to two geocomplex types (5 and 6), they have the highest share in all abandonment intensity classes, and they also cover the largest area among grounds without abandoned lands.

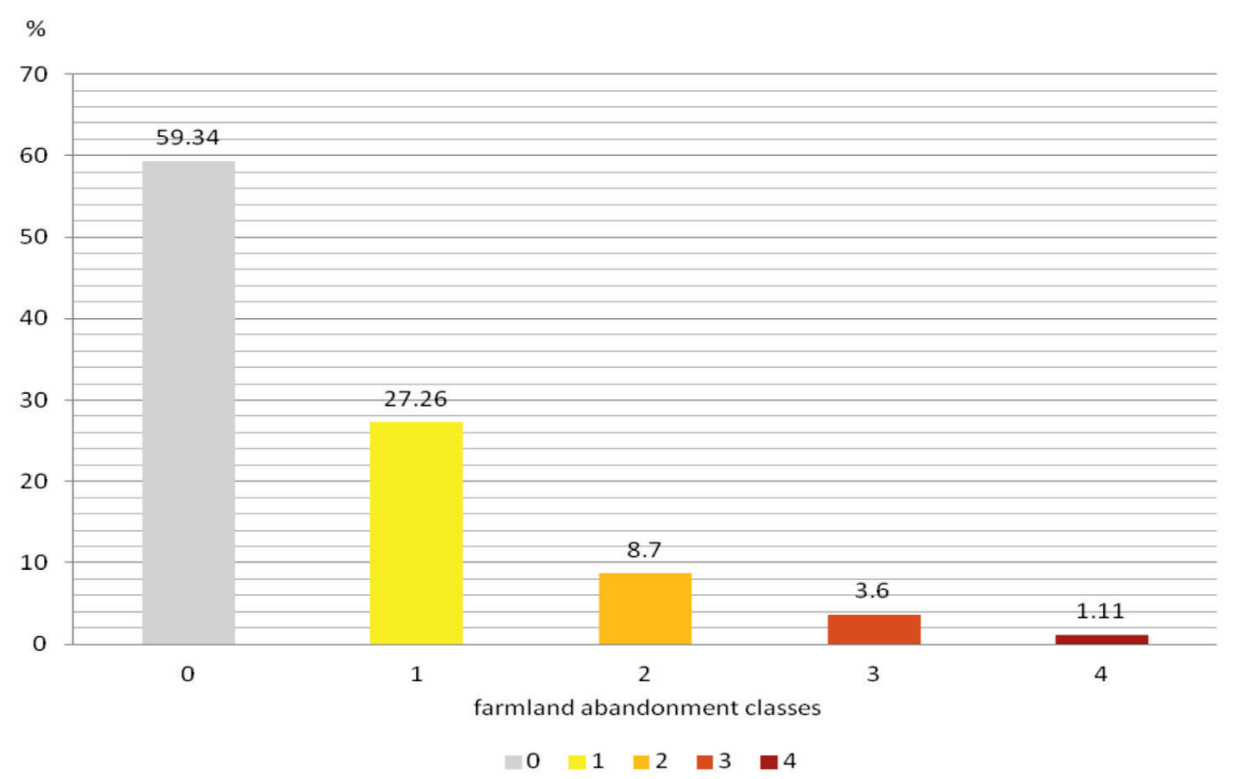

Fig. 4.5. Percentage of area of land abandonment intensity classes in the buffer zone around landscape parks on the Pilica River

Source: own elaboration

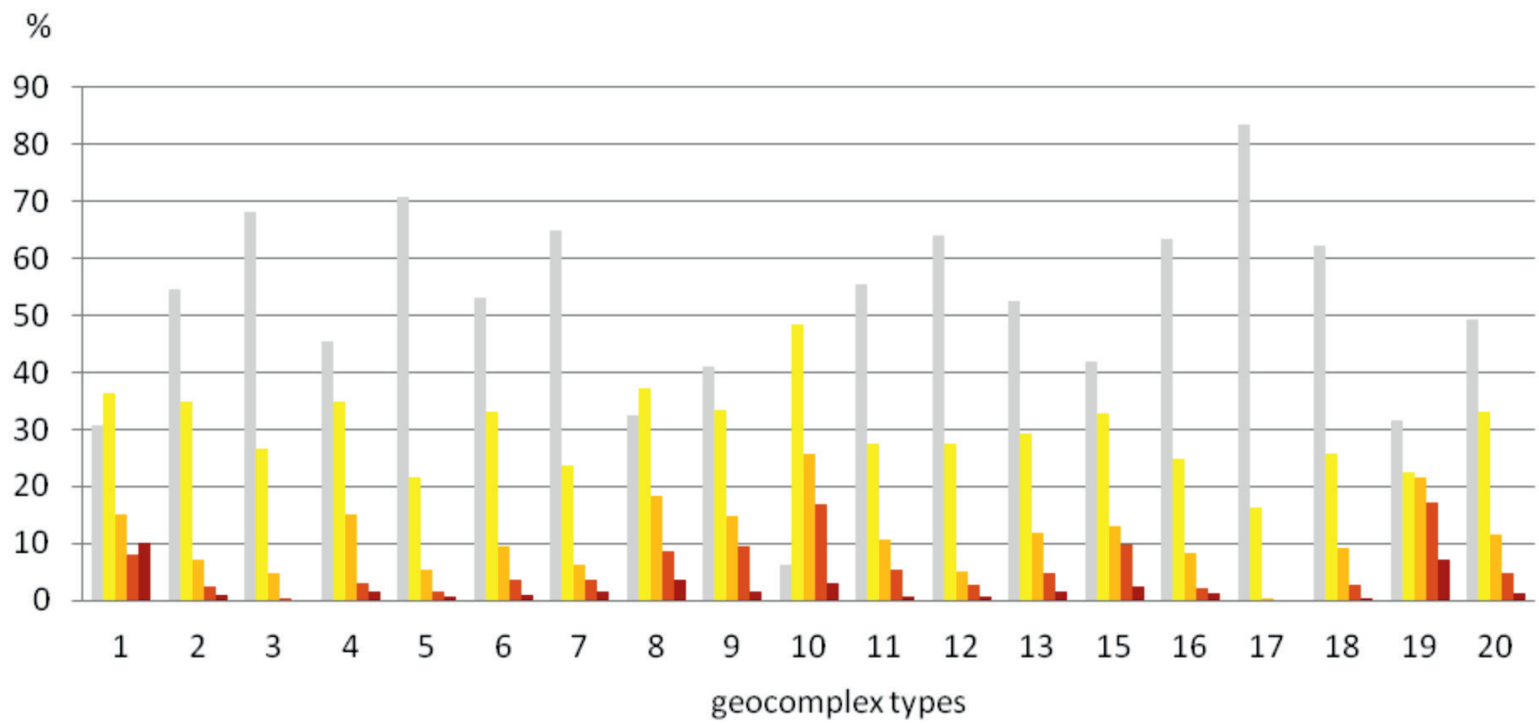

class 0 class 1 class 2 class $3 \square$ class 4

Fig. 4.6. Percentage of areas of land abandonment intensity classes in geocomplex types in the buffer zone around landscape parks on the Pilica River

Source: own elaboration 
Tab. 4.1. Percentage of areas of geocomplex types in land abandonment intensity classes in the buffer zone around landscape parks on the Pilica River (sorted by the decreasing share in the area of geocomplex type)

\begin{tabular}{|c|c|c|c|c|c|c|c|c|c|}
\hline \multirow{2}{*}{$\begin{array}{l}\text { Geocom- } \\
\text { plex type }\end{array}$} & $\begin{array}{l}\% \text { geo- } \\
\text { complex } \\
\text { type area }\end{array}$ & \multirow{2}{*}{$\begin{array}{l}\text { Geocom- } \\
\text { plex type }\end{array}$} & $\begin{array}{c}\% \text { geo- } \\
\text { complex } \\
\text { type area }\end{array}$ & \multirow{2}{*}{$\begin{array}{l}\text { Geocom- } \\
\text { plex type }\end{array}$} & $\begin{array}{l}\text { \% geo- } \\
\text { complex } \\
\text { type area }\end{array}$ & \multirow{2}{*}{$\begin{array}{l}\text { Geocom- } \\
\text { plex type }\end{array}$} & $\begin{array}{l}\text { \% geo- } \\
\text { complex } \\
\text { type area }\end{array}$ & \multirow{2}{*}{$\begin{array}{l}\text { Geocom- } \\
\text { plex type }\end{array}$} & $\begin{array}{c}\% \text { geo- } \\
\text { complex } \\
\text { type area }\end{array}$ \\
\hline & $\begin{array}{l}\text { In aban- } \\
\text { donment } \\
\text { class } 0\end{array}$ & & $\begin{array}{l}\text { In aban- } \\
\text { donment } \\
\text { class } 1\end{array}$ & & $\begin{array}{l}\text { In aban- } \\
\text { donment } \\
\text { class } 2\end{array}$ & & $\begin{array}{l}\text { In aban- } \\
\text { donment } \\
\text { class } 3\end{array}$ & & $\begin{array}{l}\text { In aban- } \\
\text { donment } \\
\text { class } 4\end{array}$ \\
\hline 5 & 43.87 & 5 & 29.14 & 5 & 22.98 & 6 & 18.97 & 5 & 21.84 \\
\hline 6 & 16.84 & 6 & 22.75 & 6 & 20.72 & 5 & 16.05 & 6 & 17.19 \\
\hline 18 & 6.22 & 20 & 8.91 & 20 & 9.75 & 9 & 11.39 & 1 & 9.57 \\
\hline 20 & 6.08 & 11 & 6.48 & 11 & 8.04 & 20 & 9.99 & 20 & 9.07 \\
\hline 11 & 6.04 & 18 & 5.60 & 9 & 7.35 & 11 & 9.96 & 15 & 6.76 \\
\hline 16 & 4.85 & 9 & 5.27 & 18 & 6.35 & 15 & 8.20 & 9 & 6.29 \\
\hline 9 & 2.98 & 16 & 4.11 & 15 & 4.48 & 18 & 4.49 & 19 & 5.43 \\
\hline 13 & 2.37 & 15 & 3.55 & 16 & 4.37 & 19 & 3.99 & 16 & 5.05 \\
\hline 12 & 2.11 & 13 & 2.87 & 13 & 3.67 & 13 & 3.58 & 11 & 4.82 \\
\hline 15 & 2.10 & 12 & 1.95 & 8 & 2.27 & 16 & 2.81 & 8 & 3.73 \\
\hline 3 & 1.33 & 8 & 1.46 & 19 & 2.07 & 8 & 2.56 & 13 & 3.50 \\
\hline 7 & 1.17 & 1 & 1.38 & 4 & 1.83 & 1 & 2.30 & 7 & 1.57 \\
\hline 2 & 0.98 & 2 & 1.38 & 1 & 1.80 & 12 & 1.51 & 4 & 1.48 \\
\hline 4 & 0.80 & 4 & 1.34 & 12 & 1.14 & 10 & 1.39 & 12 & 1.35 \\
\hline 17 & 0.68 & 3 & 1.13 & 2 & 0.89 & 7 & 1.07 & 2 & 0.87 \\
\hline 8 & 0.58 & 19 & 0.96 & 10 & 0.87 & 4 & 0.92 & 10 & 0.83 \\
\hline 1 & 0.53 & 7 & 0.93 & 7 & 0.76 & 2 & 0.73 & 18 & 0.67 \\
\hline 19 & 0.44 & 10 & 0.52 & 3 & 0.63 & 3 & 0.11 & 3 & 0.00 \\
\hline 10 & 0.03 & 17 & 0.29 & 17 & 0.02 & 17 & 0.00 & 17 & 0.00 \\
\hline
\end{tabular}

Source: own elaboration. 


\title{
4.2. Abandoned lands around the Sieradz landscape parks (Załęcze Landscape Park, Warta-Widawka Interfluve Landscape Park)
}

\author{
Elżbieta Papińska
}

The Sieradz landscape parks - the Warta-Widawka Interfluve LP and the Załęcze LP are located relatively close to each other. Because of that, the selected $10-\mathrm{km}$ wide study zones around the parks overlap, forming a vast, longitudinally stretched area, which encompasses both the right and left part of the Warta basin. The buffer zone around the Sieradz landscape parks covers the area of $1542.27 \mathrm{~km}^{2}$. It lies within the following physicogeographical units, according to J. Kondracki's regionalisation (2002): the provinces of Middle European Plain (31) and Polish Uplands (34), subprovinces of the Central Polish Lowland (318) and the Silesia-Cracow Upland (341). The lower order units in the analysed area include: macroregion of the South Greater Poland Lowland (318.1-2) with mesoregions of the Sieradz Basin (318.18), the Łask Plateau (318.19), the Złoczew Plateau (318.22), the Szczerców Basin (318.23), macroregion of the South Mazovian Hills (318.8) with mesoregion of the Bełchatów Plateau (318.81), and in the southern part of the area - macroregion of the Woźniki-Wieluń Upland (341.2) with mesoregion of the Wielun Upland (341.21). Their spatial relationships are shown in Figure 4.7.

It is noteworthy that the southern part of the analysed area is located in the transitory zone between uplands and lowlands, which is reflected among other things in the presence of Mesozoic sediments on the surface and karst forms (surface and underground karst), so characteristic of the Polish Jurassic. The characteristic curve of the Warta River is found in this zone, which changes its course from latitudinal to longitudinal, forming picturesque gorges (Krzemiński 1965, 1974, 1986, 1988; Krzemiński, Papińska 1993; Laskowski, Papińska, Tołoczko 2001; Papińska 2001ab; Papińska, Tołoczko 2002). The entire analysed area lies within the extent of the Warta Glaciation, which entered the area with its South Greater Poland lobe, reaching as far as the northern fragments of the Woźniki-Wieluń Upland (Lesser Poland). The glaciation left behind an array of glacial and fluvioglacial forms and sediments, which contribute to the fairly diverse character of the area's landscape. Other forms found in the analysed area, which provide evidence for areal deglaciation, include kames and kame terraces, kettle holes or proglacial fragments of valleys. With the retreat of the Warta Glaciation, the local erosional base was lowered and valleys were deepened. According to T. Krzemiński (1988), the Warta River cut in by $15-30 \mathrm{~m}$, and in the plateau areas during the Vistulian, aeolian sands were accumulated in the form of shields and dunes, whose topographic prominence reaches 5-10 $\mathrm{m}$. These opposite processes resulted in an increased amplitude of relative heights, which improves the visual attractiveness of the landscape.

The main axis of the characterised area is the Warta valley. In the southern part of the study area, the Mesozoic substratum influenced the direction of its flow. From Działoszyn, the river flows from east to west, to change the course by $180^{\circ}$ in a characteristic bend near Załęcze-Kępowizna, and direct its waters to the north and north-east. In its course, the most prominent features are the gorges near Działoszyn, Załęcze and Krzeczów.

In the study area, the Warta River is supplied by numerous left (e.g. the Oleśnica) and right tributaries (e.g. the Widawka). Undoubtedly, one of the most environmentally attractive fragments of the area is the Warta and Widawka interfluve, with its tributaries: Nieciecz and Grabia.

Valleys of the Widawka and its tributaries (Nieciecz and Grabia) significantly improve the attractiveness of the relief. Each of these rivers has a different valley character. The characteristic feature of the Widawka valley is the presence of peat bogs. They occur in the west slope zone and are supplied with ground water held upon tills and varved clays under a stratum of Vistulian sands of the terraces of the Warta and Widawka interfluve. Peat extraction ponds are left after exploitation of peat, with rich aquatic and rush vegetation, surrounded with nicely formed Ribeso nigri-Alnetum forest. The Grabia created a valley with all elements, fairly symmetrical with undercuts of the terraces and oxbow lakes filled with peat. The Nieciecz valley is characterised by clear features of its youth. It has a narrow bottom, which is almost completely filled with the river channel, contrasting with steep slopes. Diversity of the natural environment of the analysedareaisillustrated with themapofgeocomplexes (Fig. 4.8). The area of geocomplex types was presented in Fig. 4.9. 


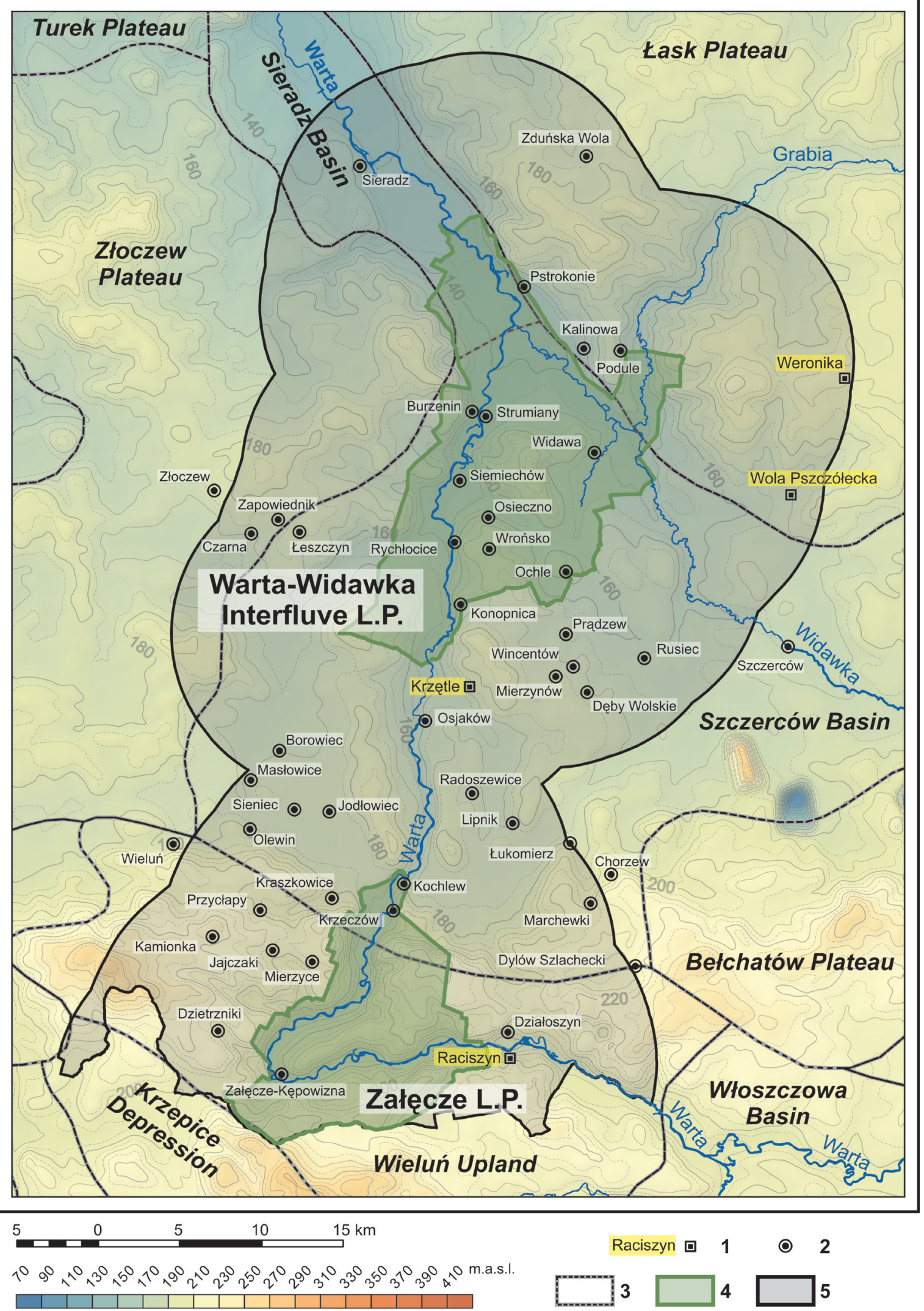

Fig. 4.7. Sieradz landscape parks and their buffer zone against the background of physicogeographical units by J. Kondracki (2002)

1 - location of abandonment study plot groups; 2 - locations mentioned in the text; 3 - boundaries of physicogeographical units; 4 - landscape park areas; 5 - 10-km wide buffer zone around landscape parks

Source: own elaboration based on digital elevation model with grid interval of at least $100 \mathrm{~m}$ and other data made available by CODGiK (www.codgik.gov.pl) 
The geocomplex map (Fig. 4.8) and data presented in Fig. 4.9 indicate that the largest portion of the spatial structure of the area is occupied by 7 geocomplex types: 5 (24.6\%), 6 (23.6\%), 16 (13.8\%), 11 (11.7\%), 8 (6.3\%) and 4 (6\%). Altogether, these geocomplex types cover $85 \%$ of the analysed surface. The spatial image of the areas (Fig. 4.10) without abandoned farmland (class 0) reveals their clear concentration in the zone located to the west and north-west of the borders of the Załęcze Landscape Park. The areas form a broad belt from Masłowice, Sieniec, Jodłowiec toward Wielun and further to the southern border of the voivodeship. Squares in class 1 of abandonment intensity $(0.1-25 \%)$ were only recorded in areas which border larger forest complexes, e.g. near Kamionka, Przycłapy, Jajczaki. A similar regularity was observed around the forest complexes near Dzietrzniki and to the south of it, as well as along the longitudinal belt of a forest complex between the borders of the Załęcze Landscape Park and Borowiec.

Larger areas without abandoned lands are found in the eastern and north-eastern side of the Załęcze Landscape Park. The first of such zones lies latitudinally from the park borders towards Pajęczno and is limited in the north and south with larger patches of forest and, in the south, with denser building development of Działoszyn, limestone quarries, and the "Warta" cement plant. Another zone, lying to the north-east of the Załęcze Landscape Park, ranges from Radoszewice through Lipnik, Łukomierz to Chorzew. Here, areas without abandoned lands occur, apart from such geocomplexes as type 5 or 18, also within semihydrogenic geocomplexes - type 13, and hydrogenic complexes - types 11 and 12 . Within this zone, both arable lands and permanent grasslands are found, which are maintained in good agricultural condition.

A uniform patch without abandoned lands is located to the south-east of the borders of the Warta-Widawka Interfluve LP, on both sides of the national road 74, near Mierzynów, Wincentów, Rusiec, Prędzew, Dęby Wolskie. In this region, two geocomplexes dominate as regards the area covered: type 5 and 16. Much smaller areas are taken by geocomplex type 18 , characterised by slightly worse habitat conditions.

Much smaller concentrations of areas without abandoned lands are observed to the east of the S8 expressway, around the Złoczew junction, near such places as Czarna, Zapowiednik, Łeszczyn and in the Grabia and Widawka interfluve near Kalinowa and Podule. Both areas are dominated by geocomplexes built of glacial till (type 5) and, around the Złoczew junction, some areas built of fluvioglacial sands and gravels upon glacial till (type 16) appear additionally. According to information included in the soil and agricultural map of the Sieradz Voivodeship (Województwo sieradzkie. Mapa glebowo-rolnicza 1977), patches of soils classified as complex 2 (good wheat) of agricultural suitability (2D - loose sands upon loam; 2B - clayey-loamy sands upon loam), and complex 4 and 5 (very good and good rye) occur there. The granulometric composition of sediments which form these soils includes light and heavy loamy sands, which have an important influence on the functioning of soils. In the remaining areas, there are no more such clear concentrations of areas without abandoned lands.

Square plots in class 1 (up to $25 \%$ of abandoned lands) dominate in the zone around the WartaWidawka Interfluve Landscape Park. They often alternate with squares without abandoned lands, forming a kind of mosaic. In many cases, class 1 squares are found near forests. A similar regularity can be observed near anthropogenic areas, mainly the urban fabric of towns and smaller settlements. A good example of this are the surroundings of such towns as Zduńska Wola, Sieradz, Złoczew or Działoszyn.

The recently built S8 expressway runs across the analysed area. Its construction required the exclusion of some land from agricultural use, and resulted in the abandonment of a considerable amount of lands. It is especially visible in the northern part of the characterised area. Near the Sieradz junction, there are basic squares included in class $2(25.1-50 \%$ of abandoned lands) and 3 (50.1-75\% of abandoned lands). A similar situation occurs near the Zduńska Wola junction and between the forest complex lying to the south of Zduńska Wola and the city itself. A greater number of squares included in class 2 occur there.

The share of areas in different classes of land abandonment intensity showed (Fig. 4.11) that highest percentage (nearly 50\%) is taken by class 1 squares (up to $25 \%$ of abandoned lands). Class 0 squares, without abandoned lands, come second with $47.5 \%$. Squares of class 2 (25-50\% of abandoned lands) cover only $2.63 \%$ of the analysed area. Basic squares in class $3(50-75 \%$ of abandoned lands) and class 4 (75-100\% of abandoned lands) have only a minimal share. 


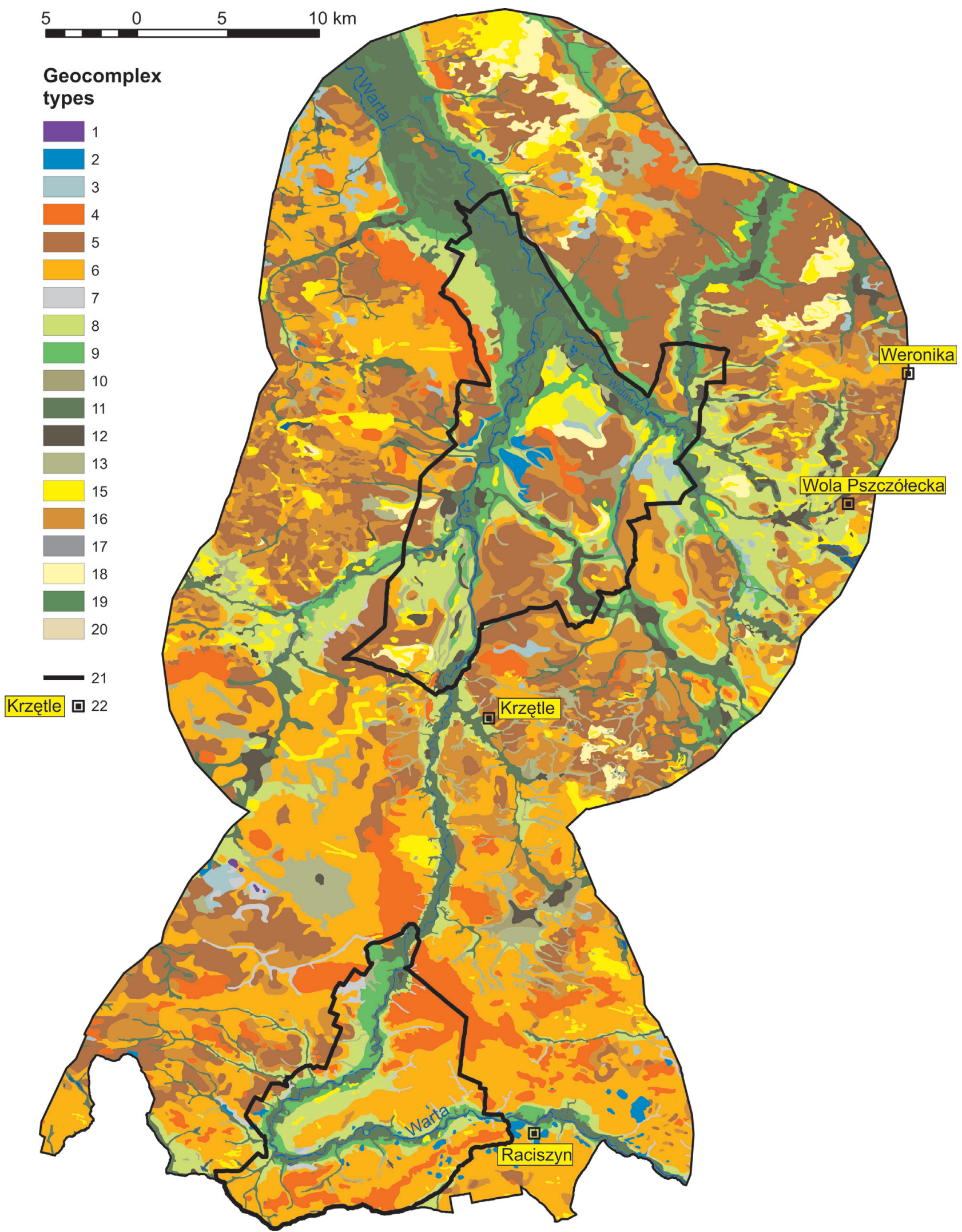

Fig. 4.8. Map of geocomplexes (morpholithohydrotopes) of the Sieradz landscape parks and their buffer zone 1-20 - names of morpholithohydrotopes are listed in Tab. 3.1; 21 - landscape park boundary; 22 - study plot group

Source: own elaboration 


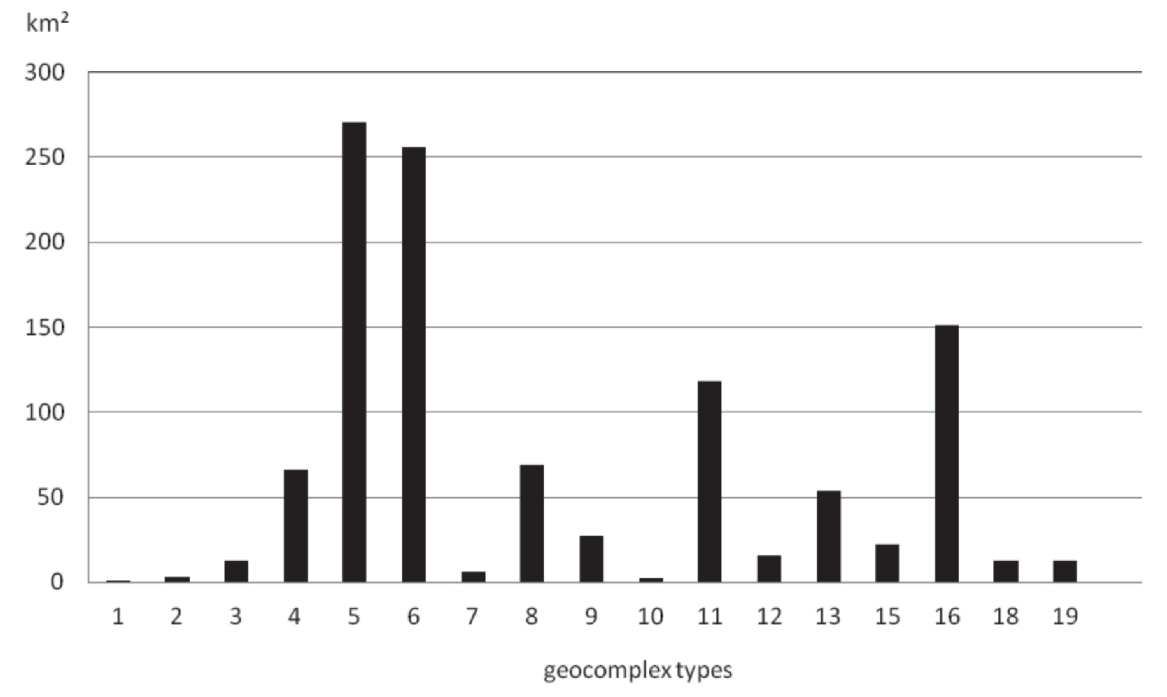

Fig. 4.9. The area of geocomplex types in the structure of the natural environment of the buffer zone around the Sieradz landscape parks

Source: own elaboration

As a result of intersecting the geocomplex map and the map of land abandonment intensity, data was obtained on the percentage of five land abandonment intensity classes in geocomplex types, as well as the percentage of geocomplex types in land abandonment intensity classes. Effects of the procedure in relation to the percentage of land abandonment intensity classes in individual geocomplex types were presented in Figure 4.12. The data shows that the highest percentage of areas without abandoned lands (class 0 ) is found in the following geocomplex types: $1-86 \%, 7-72,5 \%, 10-69 \%, 13-58 \%, 5-55,5 \%$, $16-51 \%$ and $6-$ more than $50 \%$. In the case of the first three geocomplex types $(1,7$ and 10$)$ their share in the total area of the study area is extremely low - below $1 \%$, and also the amount of these geocomplexes in class 0 of abandonment intensity is smaller than $1 \%$. A significantly larger area is taken by geocomplexes types 13,5 and 16 . Habitat conditions within these geocomplexes condition their agricultural use. The fact that such a high percentage of their area is without abandoned lands distinctly proves their substantial agricultural usefulness. A perfect example are geocomplexes of type 5 , formed of plateau glacial tills. They cover $26.4 \%$ of the area of buffer zone and over $55 \%$ of this area is characterised by lack of abandoned lands.

The lowest share of areas without abandoned lands is characteristic of geocomplex types 18 $19.6 \%$ and $15-25 \%$. In both types, aeolian sands in dunes and shields occur, but in geocomplex 18 they lie upon glacial till. In less than $25 \%$ of the area of these geocomplex types, there are no abandoned lands, however the cumulative area percentage of these types is very small (together about 3\%), and the amount of geocomplexes in class 0 of abandonment intensity equals 3.8\% for type 15 , and less than $1 \%$ for type 18 . About $70 \%$ of the area of geocomplexes of both type 18 and type 15 were included in class 1 of land abandonment intensity, which can mean that farmers tend to exclude the least productive areas from cultivation. This process probably progresses since their remaining part is taken by areas characterised by a considerable share of abandoned lands, i.e. those included in class 2 and 3 of land abandonment intensity (Fig. 4.12).

More than $50 \%$ of the area taken by class 1 of land abandonment is found in the following geocomplex types: 9, 19, 8, 11, 12 and 3 (Fig. 4.12). These geocomplexes are mostly formed of fluvial sands and muds of terraces and flood plains, which, in slope zones, are frequently characterised by excessive moisture resulting from drainage of underground water caused by the river, which promotes the development of the peat-forming process. Further from the slope, areas of terraces often show excessive dryness, as the drained ground water level lies deeper, reflecting the water level of the river. Neither of these extreme situations favours agricultural use of these geocomplex types, as they can be periodically or 


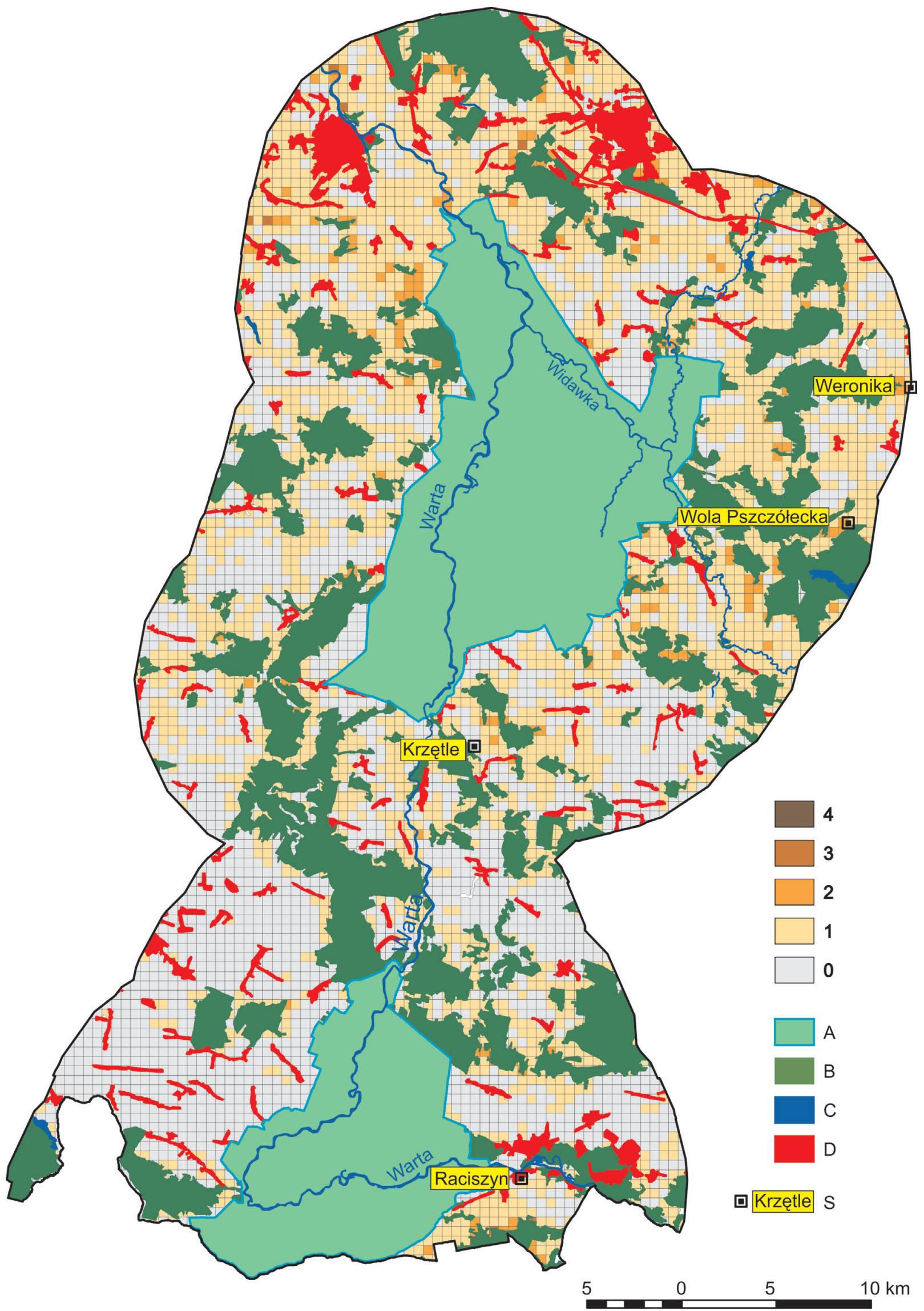

Fig. 4.10. Map of spatial distribution and intensity of land abandonment in the buffer zone around the Sieradz landscape parks. For explanation see Fig. 4.4 


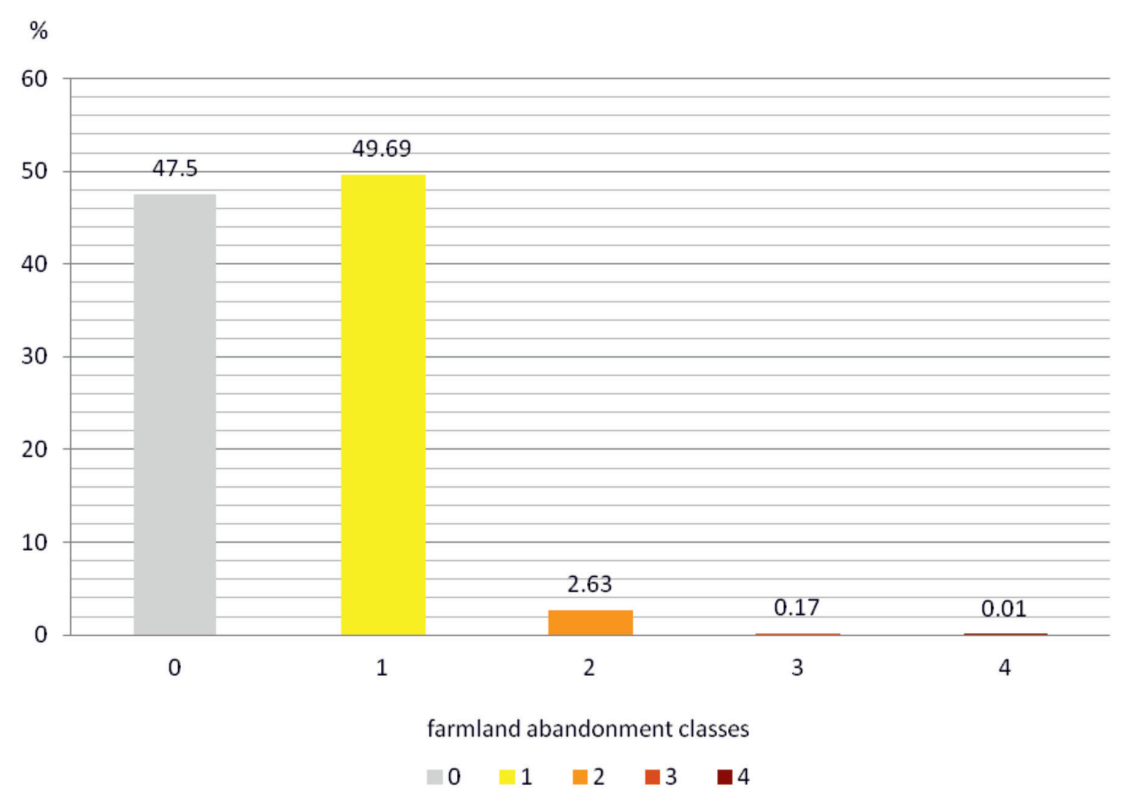

Fig. 4.11. Percentage of area of land abandonment intensity classes in the buffer zone around the Sieradz landscape parks

Source: own elaboration

permanently too moist or too dry. Geocomplex types 12 and 3 , due to the occurrence of formations on which their delimitation was based, have properties that can discourage from continuing cultivation in them. In type 12 they are peats and mucks of wetlands, which very often used to undergo drainage which allowed for their agricultural use, mainly as permanent grasslands. With time, when the efficiency of the drainage system deteriorates due to cessation of maintenance, the moisture content in these areas increases, which often renders their usage difficult or impossible. Similar situations concern geocomplex type 3, which was distinguished in areas built of clays, claystones, muds and mudstones of various origin. Low permeability of the substratum creates the possibility for the occurrence of long-term or permanent excessive moisture content if the geocomplex is not properly drained. It is also worth stressing that geocomplex types 3,12 and 19 take a relatively small portion in the study area - the share of each of them is below $1.5 \%$.

Geocomplexes which were characterised by the highest percentage of area without abandoned lands (class 0 ), have the lowest share of area included in class 1 of land abandonment intensity they are the following types: 10, 7 and 1 (Fig. 4.12).
Abandoned lands whose intensity of occurrence allowed them to be included in class 2 , clearly mark their share in the above mentioned geocomplex types: $18-8.7 \%, 15-5.4 \%$ and $4-5.8 \%$, $9-4.5 \%, 8-4.3 \%$, and $6-3.3 \%$ (Fig. 4.12). There are eight more geocomplex types with a low share of class 2 of land abandonment, ranging from $0.35 \%$ to $2.94 \%$ (Fig. 4.12 ). Three types -2 , 10,1 - are not represented in this class of land abandonment intensity.

The share of class 3 of abandoned lands in the area of geocomplexes is very low. In one case, of geocomplex type 18 , it is a little more than $1 \%$. For seven types, it ranges from 0.02 to $0.64 \%$ (Fig. 4.12). In the remaining types, there are no abandoned lands of this intensity class.

The share of class 4 of abandonment intensity is even lower - their minimal share $(0.09 \%)$ was found in geocomplex type 6 .

With the use of computer-assisted spatial analysis, results were obtained which provided information on the percentage share of area of different geocomplex types in individual classes of land abandonment intensity (Tab. 4.2). Also in this case, some regularities may be observed resulting from the predispositions created by certain geocomplex types for the development of agricultural production. 


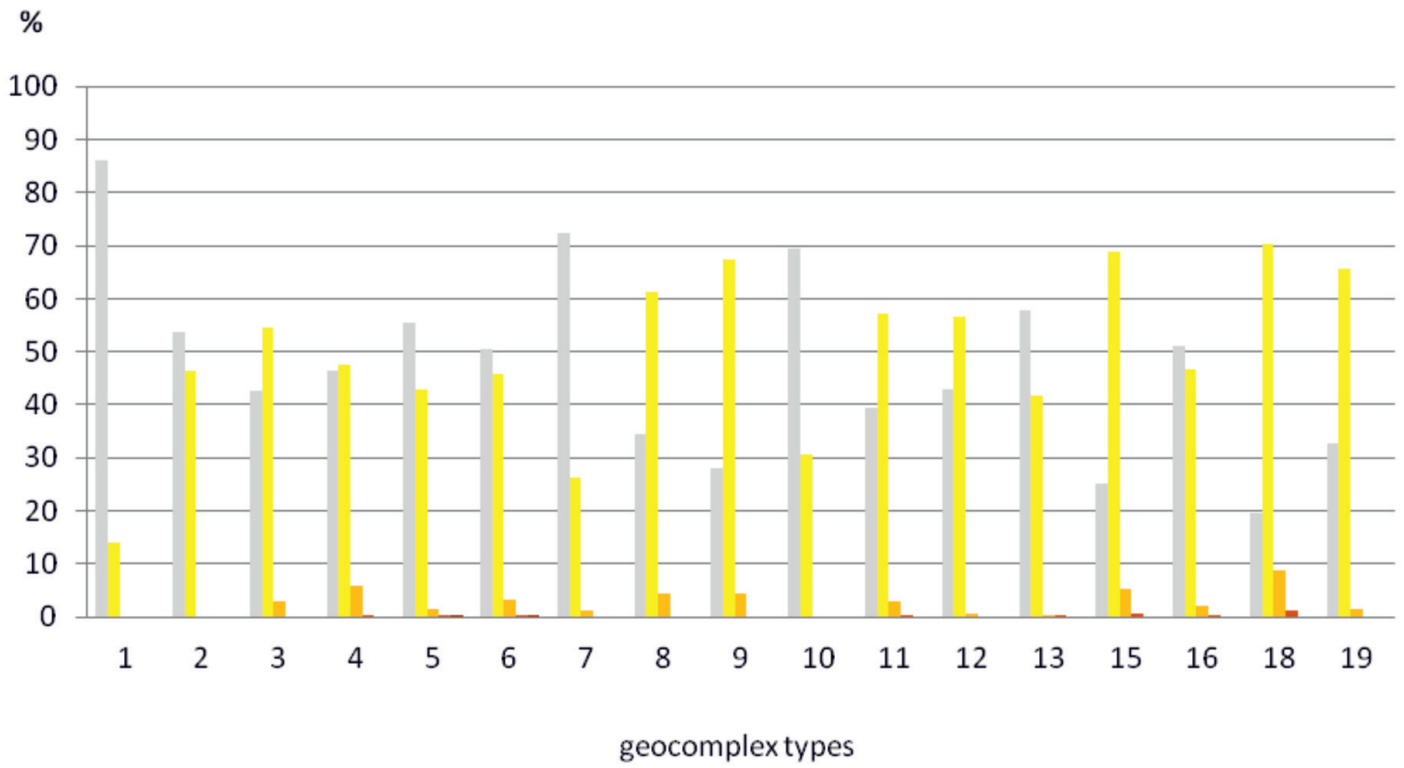

class 0 class $1 \square$ class $2 \square$ class $3 \square$ class 4

Fig. 4.12. Percentage of areas of land abandonment intensity classes in geocomplex types in the buffer zone around the Sieradz landscape parks

Source: own elaboration

Tab. 4.2. Percentage of areas of geocomplex types in land abandonment intensity classes in the buffer zone around the Sieradz landscape parks (sorted by decreasing share in the area of geocomplex type)

\begin{tabular}{|c|c|c|c|c|c|c|c|c|c|}
\hline \multirow{2}{*}{$\begin{array}{l}\text { Geocom- } \\
\text { plex type }\end{array}$} & $\begin{array}{c}\% \text { geo- } \\
\text { complex } \\
\text { type area }\end{array}$ & \multirow{2}{*}{$\begin{array}{l}\text { Geocom- } \\
\text { plex type }\end{array}$} & $\begin{array}{c}\text { \% geo- } \\
\text { complex } \\
\text { type area }\end{array}$ & \multirow{2}{*}{$\begin{array}{l}\text { Geocom- } \\
\text { plex type }\end{array}$} & $\begin{array}{c}\% \text { geo- } \\
\text { complex } \\
\text { type area }\end{array}$ & \multirow{2}{*}{$\begin{array}{l}\text { Geocom- } \\
\text { plex type }\end{array}$} & $\begin{array}{c}\% \text { geo- } \\
\text { complex } \\
\text { type area }\end{array}$ & \multirow{2}{*}{$\begin{array}{l}\text { Geocom- } \\
\text { plex type }\end{array}$} & $\begin{array}{c}\text { \% geo- } \\
\text { complex } \\
\text { type area }\end{array}$ \\
\hline & $\begin{array}{c}\text { In aban- } \\
\text { donment } \\
\text { class } 0\end{array}$ & & $\begin{array}{l}\text { In aban- } \\
\text { donment } \\
\text { class } 1\end{array}$ & & $\begin{array}{c}\text { In aban- } \\
\text { donment } \\
\text { class } 2\end{array}$ & & $\begin{array}{c}\text { In aban- } \\
\text { donment } \\
\text { class } 3\end{array}$ & & $\begin{array}{c}\text { In aban- } \\
\text { donment } \\
\text { class } 4\end{array}$ \\
\hline 5 & 28.4 & 6 & 21.7 & 6 & 28.1 & 6 & 38.1 & 6 & 77.3 \\
\hline 6 & 24.5 & 5 & 21.6 & 4 & 12.8 & 11 & 29.6 & 5 & 22.7 \\
\hline 16 & 14.6 & 16 & 13.1 & 5 & 12.4 & 18 & 10.0 & 1 & 0.0 \\
\hline 11 & 8.8 & 11 & 12.6 & 11 & 11.3 & 15 & 8.6 & 2 & 0.0 \\
\hline 13 & 5.8 & 8 & 7.9 & 16 & 10.7 & 13 & 5.9 & 3 & 0.0 \\
\hline 4 & 5.8 & 4 & 5.8 & 8 & 9.9 & 5 & 4.7 & 4 & 0.0 \\
\hline 8 & 4.5 & 13 & 4.1 & 9 & 4.1 & 16 & 2.3 & 7 & 0.0 \\
\hline 9 & 1.4 & 9 & 3.4 & 15 & 4.1 & 4 & 0.9 & 8 & 0.0 \\
\hline 12 & 1.2 & 15 & 2.9 & 18 & 3.7 & 1 & 0.0 & 9 & 0.0 \\
\hline 15 & 1.1 & 18 & 1.7 & 3 & 1.2 & 2 & 0.0 & 10 & 0.0 \\
\hline 3 & 1.0 & 12 & 1.6 & 13 & 0.6 & 3 & 0.0 & 11 & 0.0 \\
\hline 7 & 0.8 & 19 & 1.5 & 19 & 0.6 & 7 & 0.0 & 12 & 0.0 \\
\hline 19 & 0.8 & 3 & 1.3 & 12 & 0.3 & 8 & 0.0 & 13 & 0.0 \\
\hline 18 & 0.5 & 2 & 0.3 & 7 & 0.2 & 9 & 0.0 & 15 & 0.0 \\
\hline 2 & 0.4 & 7 & 0.3 & 1 & 0.0 & 10 & 0.0 & 16 & 0.0 \\
\hline 10 & 0.4 & 10 & 0.2 & 2 & 0.0 & 12 & 0.0 & 18 & 0.0 \\
\hline 1 & 0.1 & 1 & 0.0 & 10 & 0.0 & 19 & 0.0 & 19 & 0.0 \\
\hline
\end{tabular}

Source: own elaboration. 


\title{
4.3. Abandoned lands around the Łódź Hills Landscape Park and the Bolimów Landscape Park
}

\author{
Anna Majchrowska
}

The large share of urbanised area, resulting from the location of Łódź and Zgierz, is peculiar to the $10-\mathrm{km}$ wide buffer zone around the Łódź Hills Landscape Park. Research into the ecological role of abandoned farmlands included the area of
$557.3 \mathrm{~km}^{2}$ in the surroundings of the Łódz Hills Landscape Park and a part of the buffer zone around the Bolimów Landscape Park, $642.2 \mathrm{~km}^{2}$ in area, lying within the limits of the Łódź Voivodeship. In all, the study area covers $1199.5 \mathrm{~km}^{2}$.

\section{The structure of natural environment and the location of abandoned lands within the buffer zone around the Łódź Hills Landscape Park}

The buffer zone around the Łódź Hills Landscape Park includes areas of relatively diverse relief, shaped during the Cainozoic by a number of geomorphological processes, with a distinctive role of the Wartanian glacial morphogenesis (Turkowska 2006). Within the zone around the park, elevation decreases radially, most clearly to the north, descending in several characteristic steps, from the central culmination area of 284-260 m a.s.l., located along the south-western segment of the park boundary near Dąbrowa, to about 121$125 \mathrm{~m}$ a.s.l. near Wola Mąkolska (Klatkowa 1965, 1972, 1996). The land relief is varied with river valleys, running along the land's surface inclination towards the Warta, Pilica and Bzura rivers (Fig. 4.13), as well as with young erosional valleys and ravines.

Despite the relatively high relief dynamics, the entire buffer zone around the Łódź Hills Landscape Park is included in the subprovince of the Central Polish Lowland (318) and its three macroregions: the South Greater Poland Lowland (318.1-2), the Central Mazovian Lowland (318.7) and the South Mazovian Hills (318.8), represented respectively by the mesoregions of the task Plateau (318.19) - in the west, the Łowicz-Błonie Plain (318.72) - in the north, and the Łódź Hills (318.82) - in the remaining area (Fig. 4.13).

The structure of natural environment of the buffer zone around the Łódź Hills Landscape Park (Fig. 4.14) is dominated by two geocomplex types (Fig. 4.15): 6 - glacial and fluvioglacial boulders, cobbles, gravels, sands and muds of plateaus, alluvial fans and erosional-accumulational terraces (36.5\% of the area) and 5 - glacial tills of plateaus $(30 \%$ of the area). Subsequently, with significantly lower shares of 5-6\% each, there are geocomplexes of periglacial cover sands of plateaus (type 20) and glacial and fluvioglacial plateau sands and gravels upon glacial tills (type 16). Overall, these four geocomplex types cover about $79 \%$ of the area, whose characteristic features include the location at the water divide of the Vistula and Odra basins, and the lack of large rivers. Geocomplex types associated with river valleys: fluvial sands and muds and organic sediments of valley bottoms (type 11), fluvial sands and muds of the lower terrace (type 9) and fluvial sands and muds and organic sediments of terraces (type 10), constitute jointly about $7.5 \%$ of the buffer area. Very small areas, below $1 \%$ of the buffer area, are taken by geocomplex types 3,10,12 and 15 .

Within the study area, the area of land abandonment intensity square plots included in class 0 , that is without abandonment, and the area of squares with abandoned lands, have similar shares of approximately $50 \%$ (Fig. 4.16). The area of squares included in class 1 of land abandonment intensity constitutes about $30.2 \%$ of the total study area, class $2-14.2 \%$, class $3-5.2 \%$, class $4-1 \%$.

The spatial distribution of abandoned lands in the study area is irregular (Fig. 4.17) and, in general, higher land abandonment intensity is present in its western half. The largest concentrations of abandoned lands were observed in the area between Łódź, Zgierz and the Łagiewniki Forest, whose edge delimits the northern border of the Łódź Hills Landscape Park, and the line of Klęk - Czaplinek - Glinnik - Maciejów - Dąbrówka Marianka - Dąbrówka Wielka in the north. This area is dominated by squares in classes 2 and 3 of land abandonment intensity, whereas class 0 and 1 squares are sparse. The limits of dense building development of Zgierz and, to a lesser degree, of Łódź are accompanied by groups of 2-3 squares 


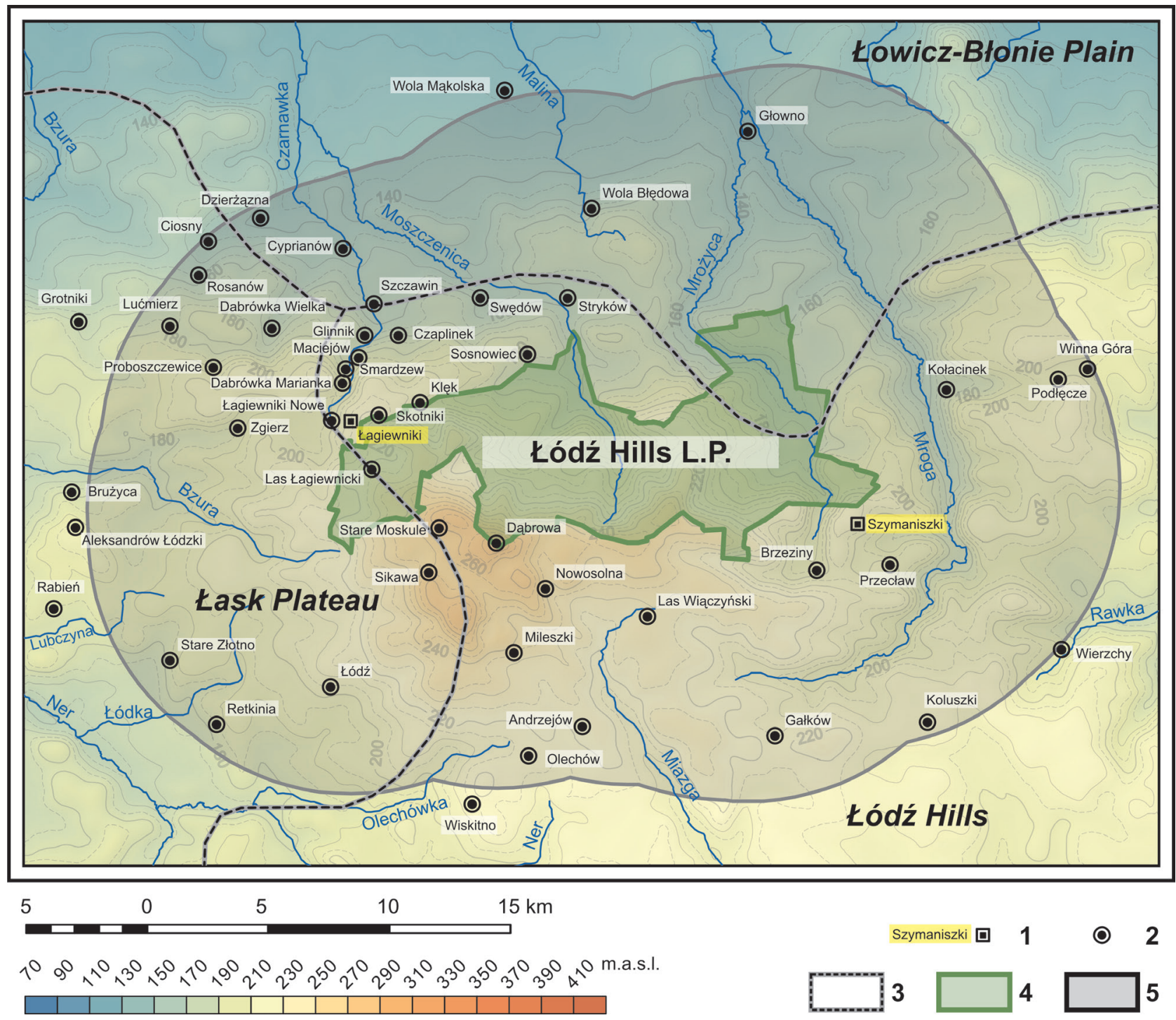

Fig. 4.13. The Łódź Hills Landscape Park and its buffer zone against the background of the physicogeographical units by Kondracki (2002)

1 - location of abandonment study plot groups; 2 - locations mentioned in the text; 3 - boundaries of physicogeographical units; 4 - landscape park area; 5 -10-km wide buffer zone around landscape park

Source: own elaboration based on digital elevation model with grid interval of at least $100 \mathrm{~m}$ and other data made available by CODGiK (www.codgik.gov.pl)

of class 4 , in which more than $75 \%$ of the area is taken by abandoned lands. Increased land abandonment intensity was also recorded to the west of Zgierz, near Proboszczewice and along the Bzura valley to Brużyca Wielka.

Extensive concentrations of abandoned lands are also found in the eastern part of Łódź, within its administrative borders, in the belt encompassing parts of Stare Moskule in the north, Sikawa and Nowosolna, as well as Mileszki and Andrzejów, and Wiskitno - to the south of the railway and the Łódź Olechów station, to the Olechówka valley. Most of them are villages and their gro- unds incorporated into Łódź in 1988. In this zone, land abandonment intensity is the highest in the central part - between Sikawa and Nowosolna, where there are several squares of class 4 of land abandonment intensity, i.e. taken almost entirely by abandoned lands. Apart from that, squares included in classes 1, 2 and 3 occur here in similar proportions. Basic squares without abandoned lands occur sporadically. Other clusters of class 4 squares, usually accompanied by class 2 and 3 squares, are found near Stryków, within a triangle marked by Sosnowiec, Wola Błędowa and the junction of A1 and A2 motorways. Smaller 


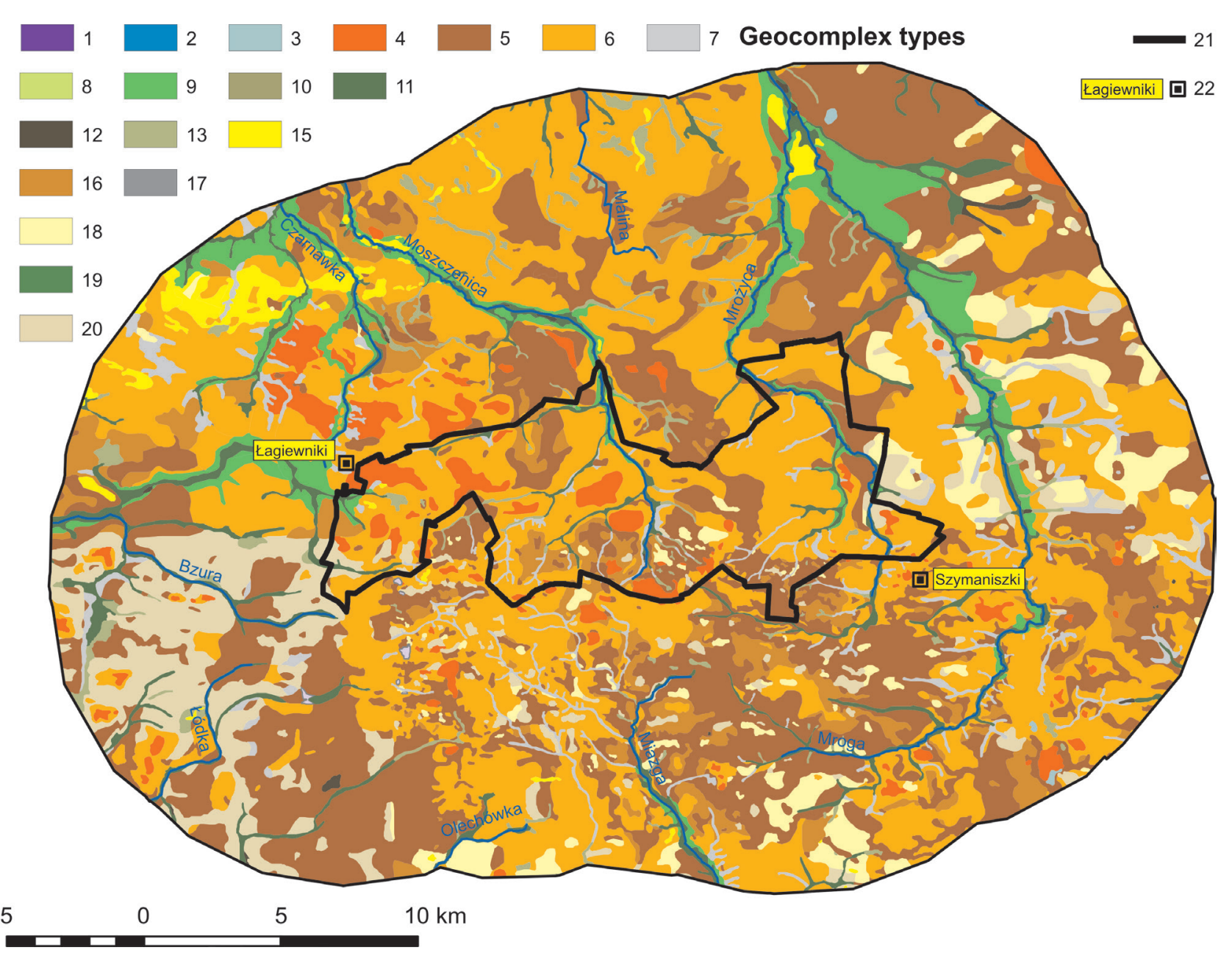

Fig. 4.14. Map of geocomplexes (morpholithohydrotopes) of the Łódź Hills Landscape Park and its buffer zone 1-20 - names of the morpholithohydrotope types listed in Tab. 3.1; 21 - landscape park boundary;

22 - study plot group

Source: own elaboration

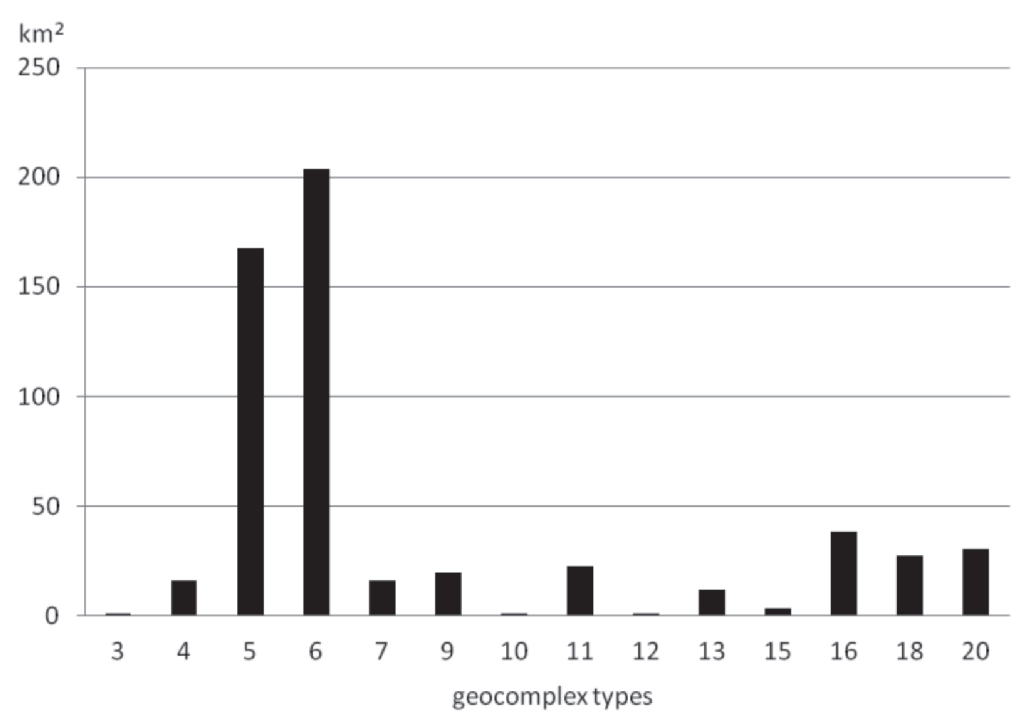

Fig. 4.15. The area of geocomplex type in the structure of the natural environment of the buffer zone around the Łódź Hills Landscape Park

Source: own elaboration 


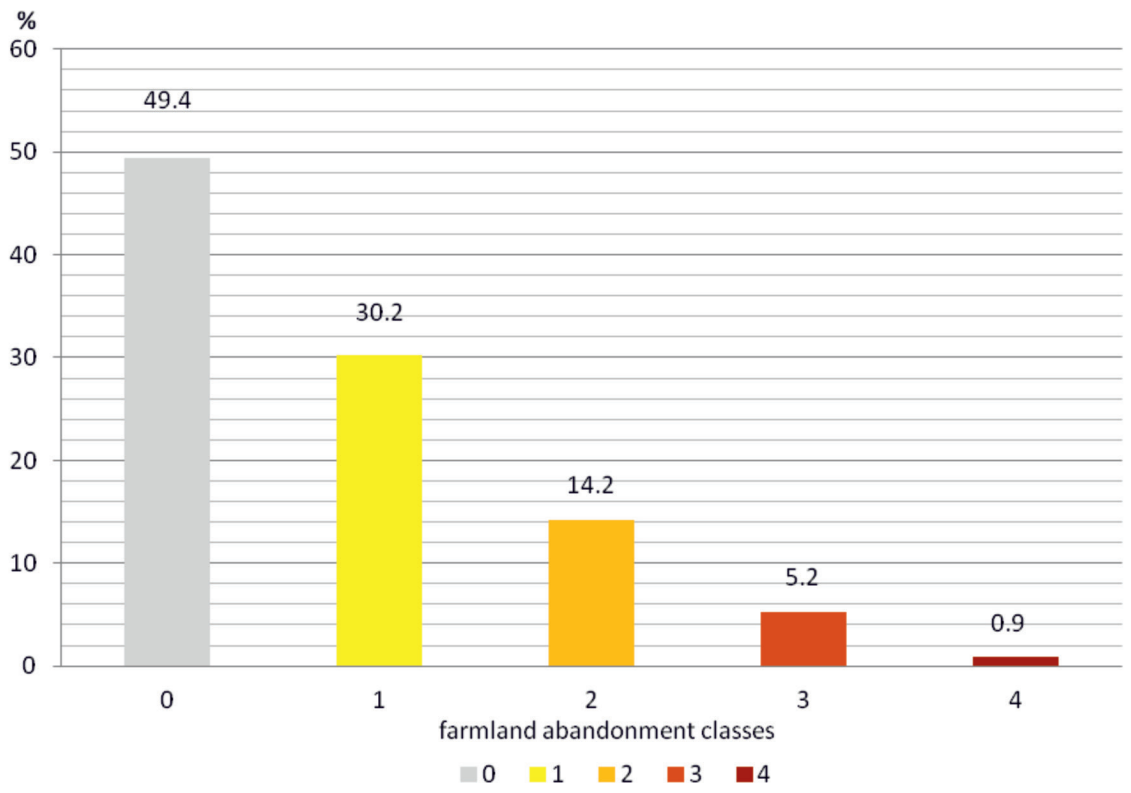

Fig. 4.16. Percentage of the areas of land abandonment intensity classes in the buffer zone around the Łódź Hills Landscape Park

Source: own elaboration

concentrations of abandoned lands in the western part of the described area are marked in the following locations: near Dzierzążna, Ciosny and Rosanów, near Cyprianów, near Rąbień AB, Stare Złotno and Retkinia.

In the eastern half of the buffer zone, the only larger concentration of plots assigned to classes 3 and 4 of abandonment intensity was found between Brzeziny and the southern border of the landscape park, along the Mrożyca valley. Only one concentration of abandonment class 2 and 3 squares is found in the south-eastern part of the analysed area - near Koluszki.

The remaining, usually not numerous, squares of class 4 of abandonment intensity, scattered across the entire study area, encompass forest-field ecotones.

The lowest abandonment intensity in the analysed area occurs in its northern, north-eastern and eastern parts. In these areas, class 0 squares of land abandonment intensity, i.e. those without any abandoned lands, prevail definitely. There are a few class 2 squares, whereas class 1 squares, concentrated in small groups, accompany patches of forest and river valleys. A belt of class 1 and sporadic class 2 squares lies along the Mroga and Mrożyca valleys. Low abandonment rates also characterise the upper part of the Mroga catchment basin, between the Wiaczyn Forest, Gałków Duży and Brzeziny and Przecław.
Based on the comparison between the map of geocomplexes and the map of abandoned land distribution, the share of different abandonment intensity classes was determined in individual geocomplex types (Fig. 4.18). The results indicate that farmlands with no abandonment (class 0) have the highest share in the area of lithogenic complexes: type 3 - clays, claystones, muds and mudstones of various origin (a very low share of the geocomplex type in the study area), 18 plateau periglacial silts and aeolian sands upon glacial till, and 5 - plateau glacial tills and - with hydrologic conditions shaped partially by shallow low permeable formations.

The lowest share of class 0 squares occurs in the geocomplex types with highly permeable soils, vulnerable to drying: aeolian sands of dunes and shields (type 15), boulders, cobbles, gravels, sands and muds of moraine hills and kame hills (type 4), and fluvial sands and muds of the lower terrace (type 9) (Fig. 4.18).

Classes with the highest abandonment intensity: 2, 3 and 4, have the highest share in the following geocomplex types: 4 - boulders, cobbles, gravels, sands and muds of moraine hills and kame hills, 15 - aeolian sands of dunes and shields, type 10 - fluvial sands and muds and organic sediments of the terrace, and 7 - sands, silts and muds in bottoms of dry valleys. The lowest share of intense abandonment classes is characte- 


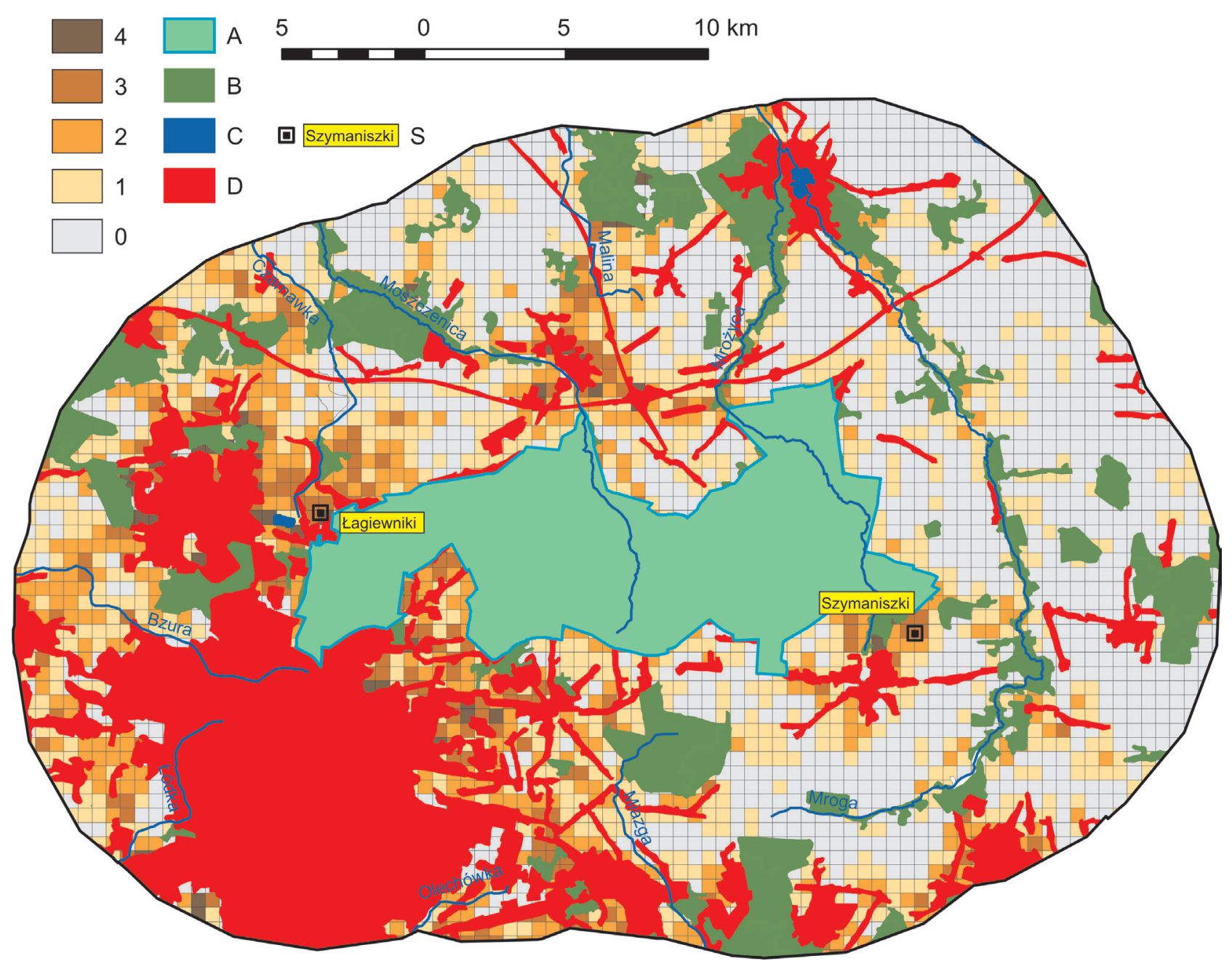

Fig. 4.17. Map of spatial distribution and intensity of land abandonment in the buffer zone around the Łódź Hills Landscape Park. For explanation see Fig. 4.4

Source: own elaboration

ristic of the following geocomplex types: 18 - plateau periglacial silts and aeolian sands upon glacial tills; 13 - mineral and organic formations in depressions of kettle holes, blowouts, spring niches and basin valleys, which is a semihydrogenic geocomplex, with periodically increased moisture content, and 5 - plateau glacial tills. Also geocomplex type 12 - peats and mucks of wetlands, contains little abandoned lands.

The percentage of geocomplex type area in land abandonment intensity classes (Tab. 4.3) in- dicates an increase of geocomplex type 6 area in higher intensity classes. Type 6 constitutes nearly $50 \%$ of the area in classes 3 and 4 of abandonment intensity. The percentage of area of several geocomplex types fluctuates in higher abandonment intensity classes. Generally, the percentage of types 20, 9 and 4 increases when intensity of abandonment grows. The percentage of geocomplex types 5, 16 and 18 decreases with increased abandonment intensity, but even in classes 3 and 4 it remains quite high. 


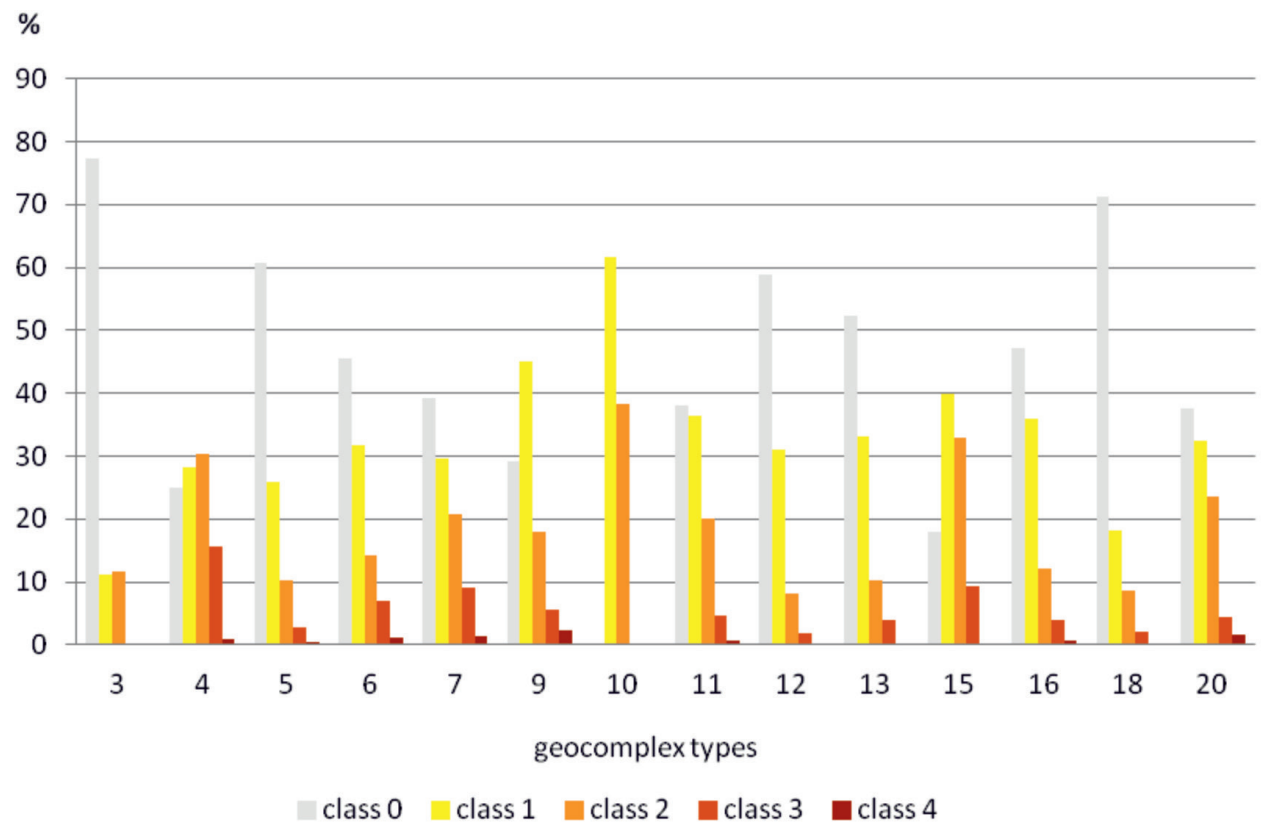

Fig. 4.18. Percentage of the area of land abandonment intensity classes in geocomplex types in the buffer zone around the Łódź Hills Landscape Park

Source: own elaboration

Table 4.3. Percentage of areas of geocomplex types in land abandonment intensity classes in the buffer zone around the Łódź Hills Landscape Park (sorted by decreasing share in geocomplex type area)

\begin{tabular}{|c|c|c|c|c|c|c|c|c|c|}
\hline \multirow{2}{*}{$\begin{array}{l}\text { Geocom- } \\
\text { plex type }\end{array}$} & $\begin{array}{c}\% \text { geo- } \\
\text { complex } \\
\text { type area }\end{array}$ & \multirow{2}{*}{$\begin{array}{l}\text { Geocom- } \\
\text { plex type }\end{array}$} & $\begin{array}{c}\% \text { geo- } \\
\text { complex } \\
\text { type area }\end{array}$ & \multirow{2}{*}{$\begin{array}{l}\text { Geocom- } \\
\text { plex type }\end{array}$} & $\begin{array}{c}\% \text { geo- } \\
\text { complex } \\
\text { type area }\end{array}$ & \multirow{2}{*}{$\begin{array}{l}\text { Geocom- } \\
\text { plex type }\end{array}$} & $\begin{array}{c}\% \text { geo- } \\
\text { complex } \\
\text { type area }\end{array}$ & \multirow{2}{*}{$\begin{array}{l}\text { Geocom- } \\
\text { plex type }\end{array}$} & $\begin{array}{l}\% \text { geo- } \\
\text { complex } \\
\text { type area }\end{array}$ \\
\hline & $\begin{array}{l}\text { In aban- } \\
\text { donment } \\
\text { class } 0\end{array}$ & & $\begin{array}{l}\text { In aban- } \\
\text { donment } \\
\text { class } 1\end{array}$ & & $\begin{array}{l}\text { In aban- } \\
\text { donment } \\
\text { class } 2\end{array}$ & & $\begin{array}{l}\text { In aban- } \\
\text { donment } \\
\text { class } 3\end{array}$ & & $\begin{array}{l}\text { In aban- } \\
\text { donment } \\
\text { class } 4\end{array}$ \\
\hline 5 & 36.87 & 6 & 38.32 & 6 & 36.85 & 6 & 48.94 & 6 & 47.45 \\
\hline 6 & 33.74 & 5 & 25.66 & 5 & 21.66 & 5 & 15.51 & 5 & 15.58 \\
\hline 18 & 7.01 & 16 & 8.09 & 20 & 9.14 & 4 & 8.47 & 20 & 9.30 \\
\hline 16 & 6.49 & 20 & 5.90 & 4 & 6.04 & 16 & 5.24 & 9 & 8.68 \\
\hline 20 & 4.19 & 9 & 5.21 & 11 & 5.82 & 7 & 5.01 & 16 & 4.52 \\
\hline 11 & 3.15 & 11 & 4.94 & 16 & 5.80 & 20 & 4.71 & 7 & 4.45 \\
\hline 7 & 2.30 & 18 & 2.91 & 9 & 4.42 & 11 & 3.73 & 4 & 2.87 \\
\hline 13 & 2.18 & 7 & 2.83 & 7 & 4.22 & 9 & 3.71 & 11 & 2.45 \\
\hline 9 & 2.06 & 4 & 2.65 & 18 & 2.94 & 18 & 1.89 & 18 & 0.56 \\
\hline 4 & 1.44 & 13 & 2.26 & 13 & 1.48 & 13 & 1.57 & 13 & 0.39 \\
\hline 12 & 0.25 & 15 & 0.76 & 15 & 1.34 & 15 & 1.02 & 12 & 0.00 \\
\hline 15 & 0.21 & 12 & 0.22 & 12 & 0.12 & 12 & 0.07 & 15 & 0.00 \\
\hline 3 & 0.07 & 3 & 0.02 & 3 & 0.04 & 3 & 0.00 & 3 & 0.00 \\
\hline 10 & 0.00 & 10 & 0.01 & 10 & 0.01 & 10 & 0.00 & 10 & 0.00 \\
\hline
\end{tabular}

Source: own elaboration. 


\section{The structure of natural environment and the location of abandoned lands around the Bolimów Landscape Park}

According to J. Kondracki's regionalisation (2002), the 10-kilometre wide buffer zone around the Bolimów Landscape Park lies in the subprovince of the Central Poland Lowland (318). Lower order units in the characterised area include: the macroregion of the Central Mazovian Lowland (318.7) with mesoregions of the Kutno Plain (318.71) in the north-east and the Łowicz-Błonie Plain (318.72) - in the centre, and the macroregion of the South Mazovian Hills (318.8) with the Rawka Plateau (318.83) in the southern part, as well as a small fragment of the Łódź Hills (318.82) - in the south-west (Fig. 4.19).

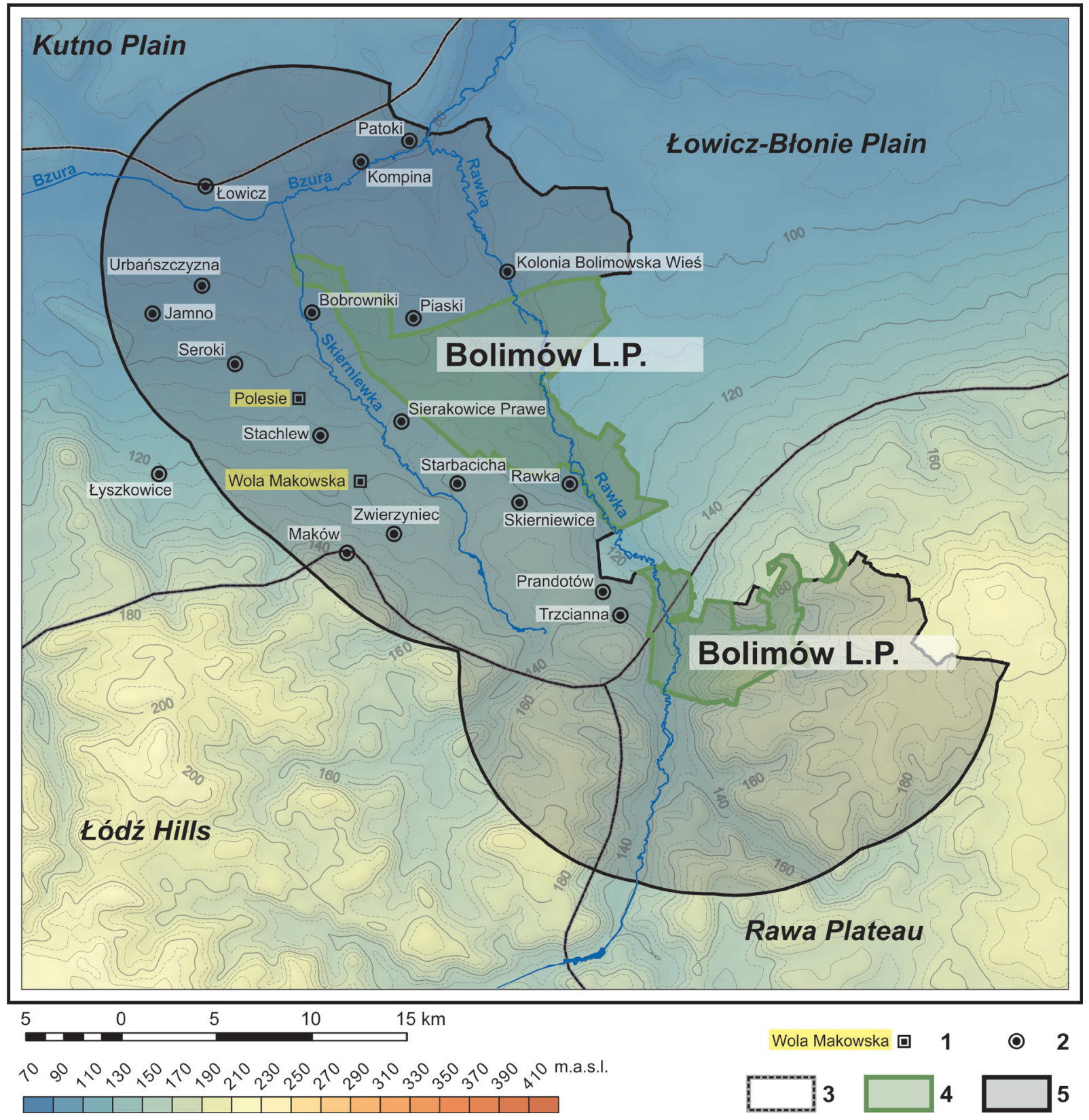

Fig. 4.19. The Bolimów Landscape Park and its buffer zone against the background of the physicogeographical units by J. Kondracki (2002)

1 - location of abandonment study plot groups; 2 - locations mentioned in the text; 3 - boundaries of physicogeographical units; 4 - landscape park area; 5 - 10-km wide buffer zone around the landscape park

Source: own elaboration based on digital elevation model with grid interval of at least $100 \mathrm{~m}$ and other data made available by CODGiK (www.codgik.gov.pl) 
The surroundings of the Bolimów Landscape Park are dominated by flat or undulated landscapes with a general south-to-north inclination. The elevation difference ranges from about 180 to $82-85 \mathrm{~m}$ a.s.l. and begins in the area of a glacial plateau with forms of crevasse accumulation through lower plateau levels - erosional and accumulational - and the terraces of the Warsaw-Berlin ice marginal valley, to the bottom of the valley. At some locations, slopes of the plateau and terraces of the ice marginal valley, cut by the Bzura river tributaries, are covered with patches of sandy-gravelly sediments of alluvial fans or aeolian sands (Rdzany 2014). In this area, segments of the Rawka valley with naturally meandering river are the characteristic features.
The structure of the natural environment of the Bolimów Landscape Park buffer zone (Fig. 4.20, 4.21) is dominated by plateau glacial tills (geocomplex type 5), which cover $40.2 \%$. Then, with a much lower share, there are geocomplex types 6 and 16, which take up respectively $17.7 \%$ and $12.2 \%$ of the area. The total area of the three geocomplex types associated with river valleys: fluvial sands and muds of lower terraces (type 9), fluvial sands, muds and organic sediments of valley bottoms (type 11), and fluvial sands and gravels of upper terraces (type 8) constitutes almost $15 \%$ of the buffer zone area. In all, these six geocomplex types occupy over $85 \%$ of the study area.

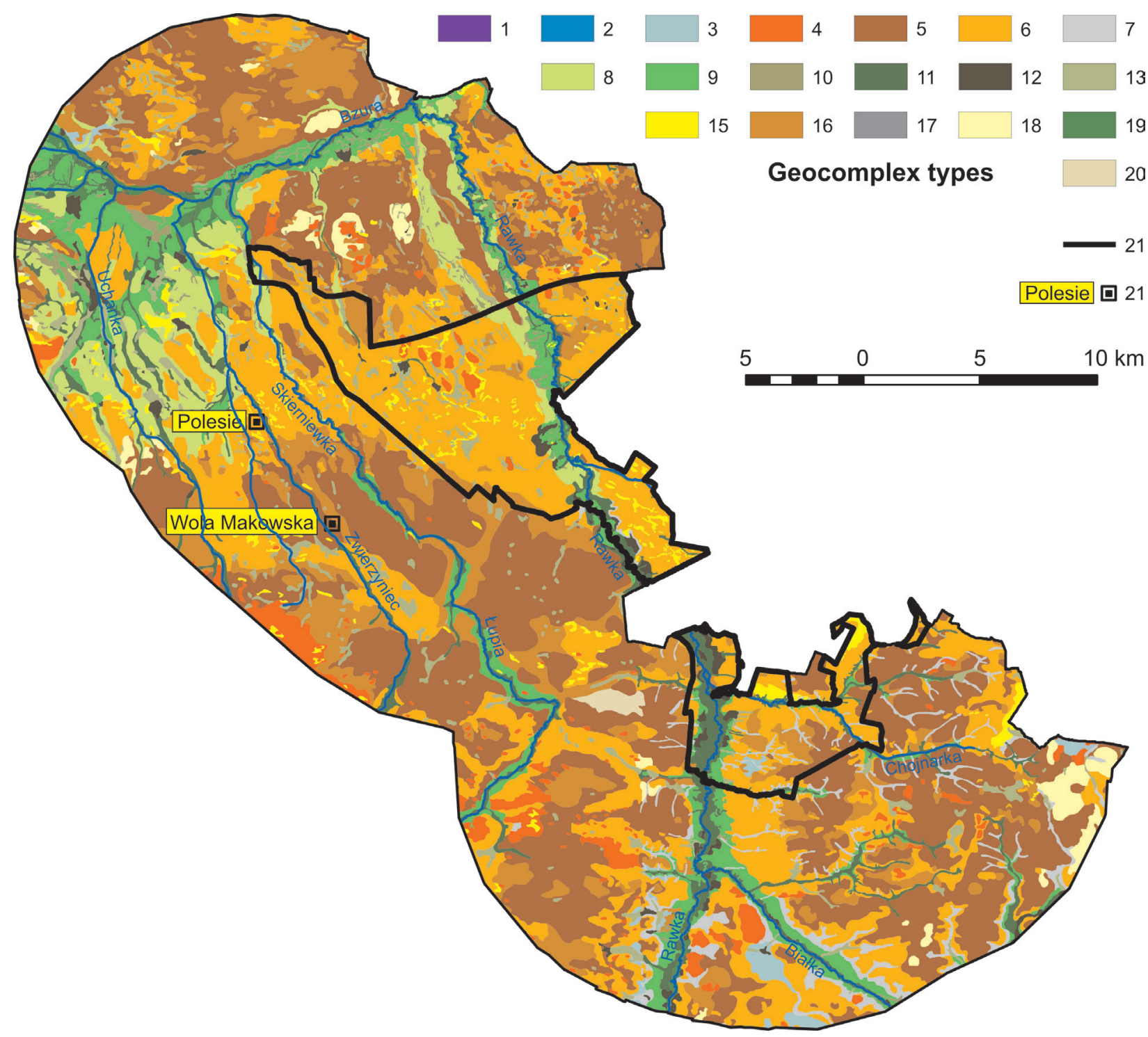

Fig. 4.20. Map of geocomplexes (morpholithohydrotopes) of the Bolimów Landscape Park and its buffer zone 1-20 - names of the morpholithohydrotopes listed in Tab. 3.1; 21 - landscape park boundary;

$$
22 \text { - study plot group }
$$

Source: own elaboration 


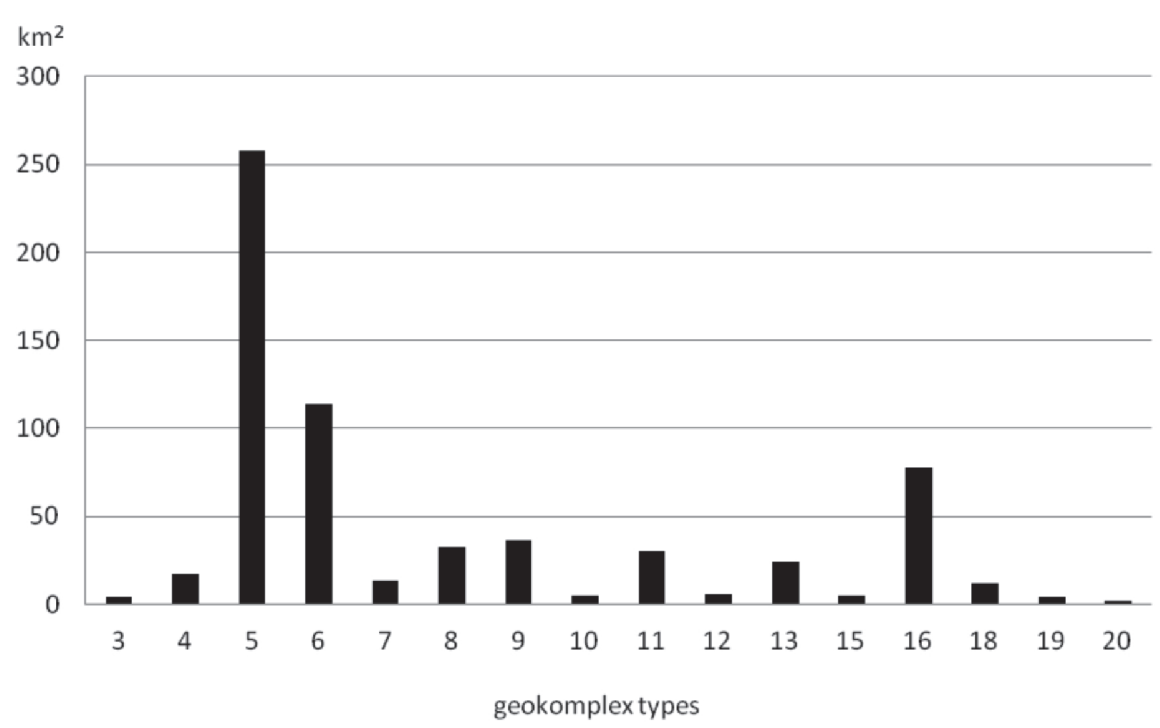

Fig. 4.21. The area of geocomplex types in the structure of the natural environment of the buffer zone around the Bolimów Landscape Park and its surroundings

Source: own elaboration

The 10-kilometre buffer zone of the Bolimów Landscape Park is characterised by lower intensity of land abandonment than the surroundings of the Łódź Hills Landscape Park, since the phenomenon of land abandonment was only found in one third of the analysed squares plots. The squares included in class 1 of land abandonment intensity cover about $26 \%$ of the area of the analysed farmlands, class $2-6.3 \%$, class $3-1.4 \%$, class 4 - less than $0.5 \%$ (Fig. 4.22). Areas free from abandonment take up about $66 \%$ of the study area.

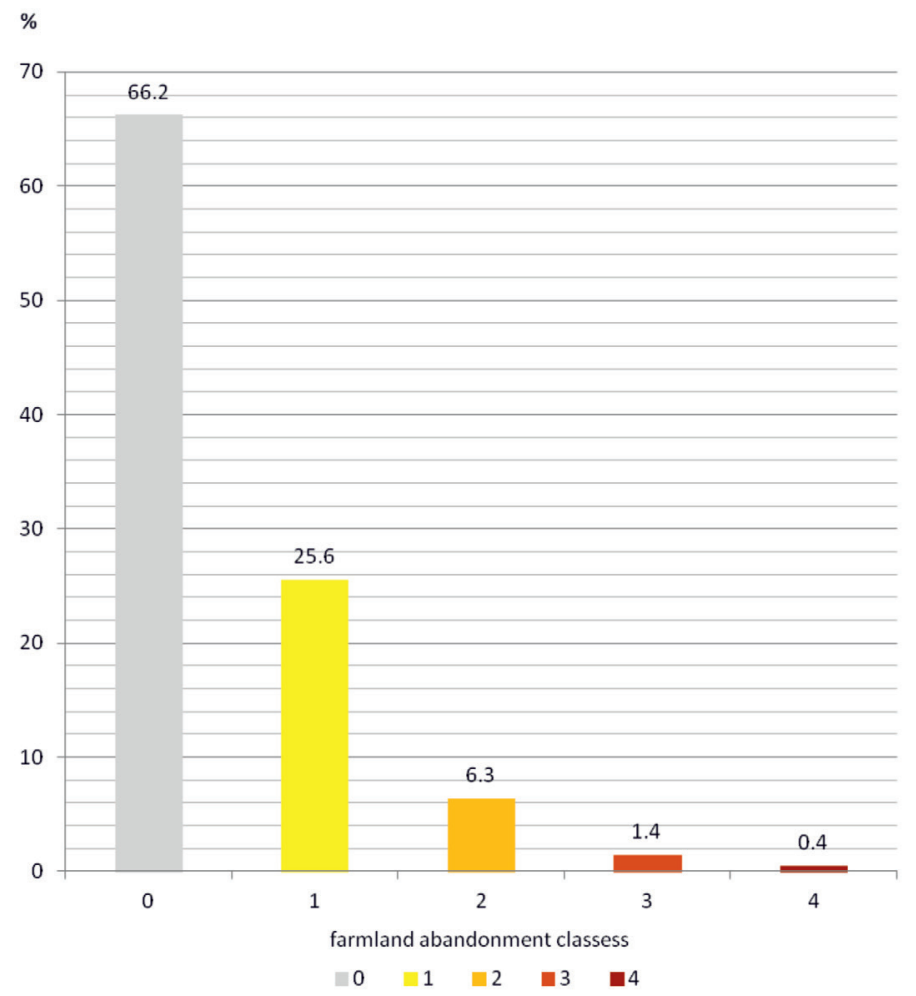

Fig. 4.22. Percentage of areas of land abandonment intensity classes in the buffer zone around the Bolimów Landscape Park

Source: own elaboration 
Arable lands without abandonment (class 0 of land abandonment intensity) are concentrated in the northern and south-eastern part of the study area (Fig. 4.23). In the north, the loamy Kutno Plain stands out, clearly dominated by plateau glacial till (geocomplex type 5), where even squares with a low share of abandoned lands (class 1) occur incidentally. Areas without abandoned lands surround Łowicz from the north, forming an arch between Jamno in the west and Kompina and Patoki in the east. Some very extensive areas with very little abandoned lands are also found to the south and south-east of Pradontów and Trzcianna and the Łupia valley in the west, in an arch around the Park borders up to the eastern limit of the study area, across almost the entire width of the buffer zone. In this area, an increased incidence of squares of class 1 and 2 of abandonment intensity is marked along the Rawka and Białka valleys and near forests.

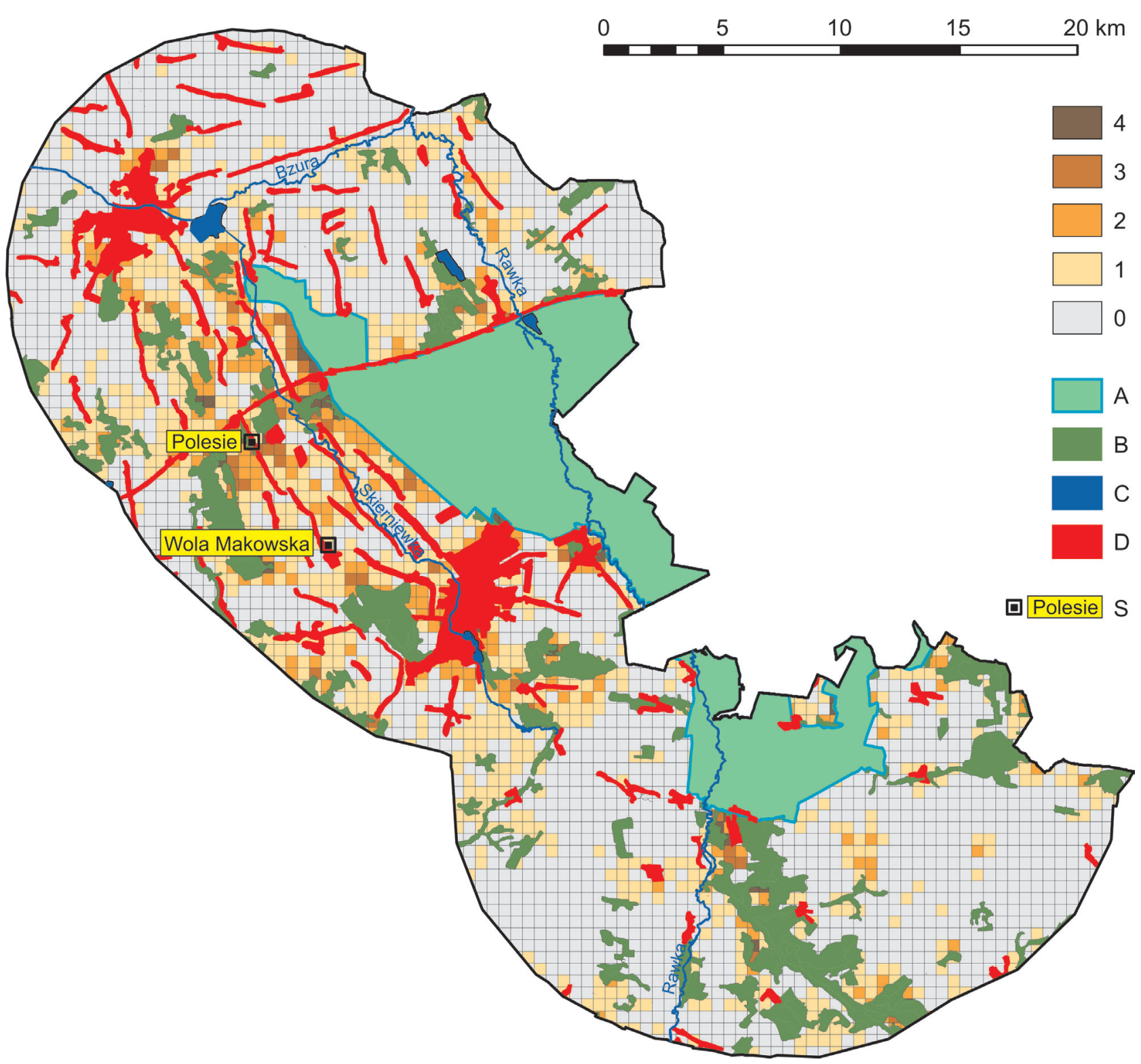

Fig. 4.23. Map of spatial distribution and intensity of land abandonment in the buffer zone around the Bolimów Landscape Park. For explanation see Fig. 4.4

Source: own elaboration 
The highest intensity of land abandonment is visible in the central and central-west part of the buffer zone around the park, between Łowicz and Skierniewice, and particularly in the belt stretching from Urbańszczyzna, through Polesie and Stachlew to the Zwierzyniec Forest. In this area, similar proportions of class 1, 2 and 3 squares occur, whereas class 4 squares, which come in groups of two or three, are found near the forests around Wola Makowska, Polesie and Seroki. A very high intensity of abandonment was also recorded in the area stretching between Skierniewice and the Bolimów Landscape Park, in Starbacicha and Rawka quarters, and, also near the border of the park, in the belt between Sierakowice Prawe and Bobrowniki. In these areas, groups of two or three squares of the highest abandonment intensity class occur, as well as numerous class 1, 2 and 3 squares. A grouping of squares with a slightly lower abandonment intensity lies along the northern border of the park and the A2 motorway, between Piaski and Kolonia Bolimowska
Wieś. A cluster of abandonment intensity class 1 squares with some class 2 and 3 squares is found here. The above mentioned areas of intensified land abandonment resemble the location of geocomplex types 6,15 and 8, with low agricultural usability.

A comparison between the geocomplex map and the map of abandonment intensity classes (Fig. 4.24) shows that the highest percentage of areas with no abandonment (class 0 ) occurs in lithogenic geocomplex types: 20 - periglacial cover sands and silts of plateaus, 18 - periglacial and aeolian sands upon glacial tills of plateaus, and 5 - glacial tills of plateaus. The lowest amount of squares included in class 0 occurs in the types of geocomplexes with highly permeable soils, prone to drying: types 15,4 , as well as 6 and 8 . There is a clear decrease in the share of geocomplex type 5 , formed of glacial tills of plateaus, with increasing abandonment intensity, accompanied by an increase in the share of geocomplex type 6 (Tab. 4.4).

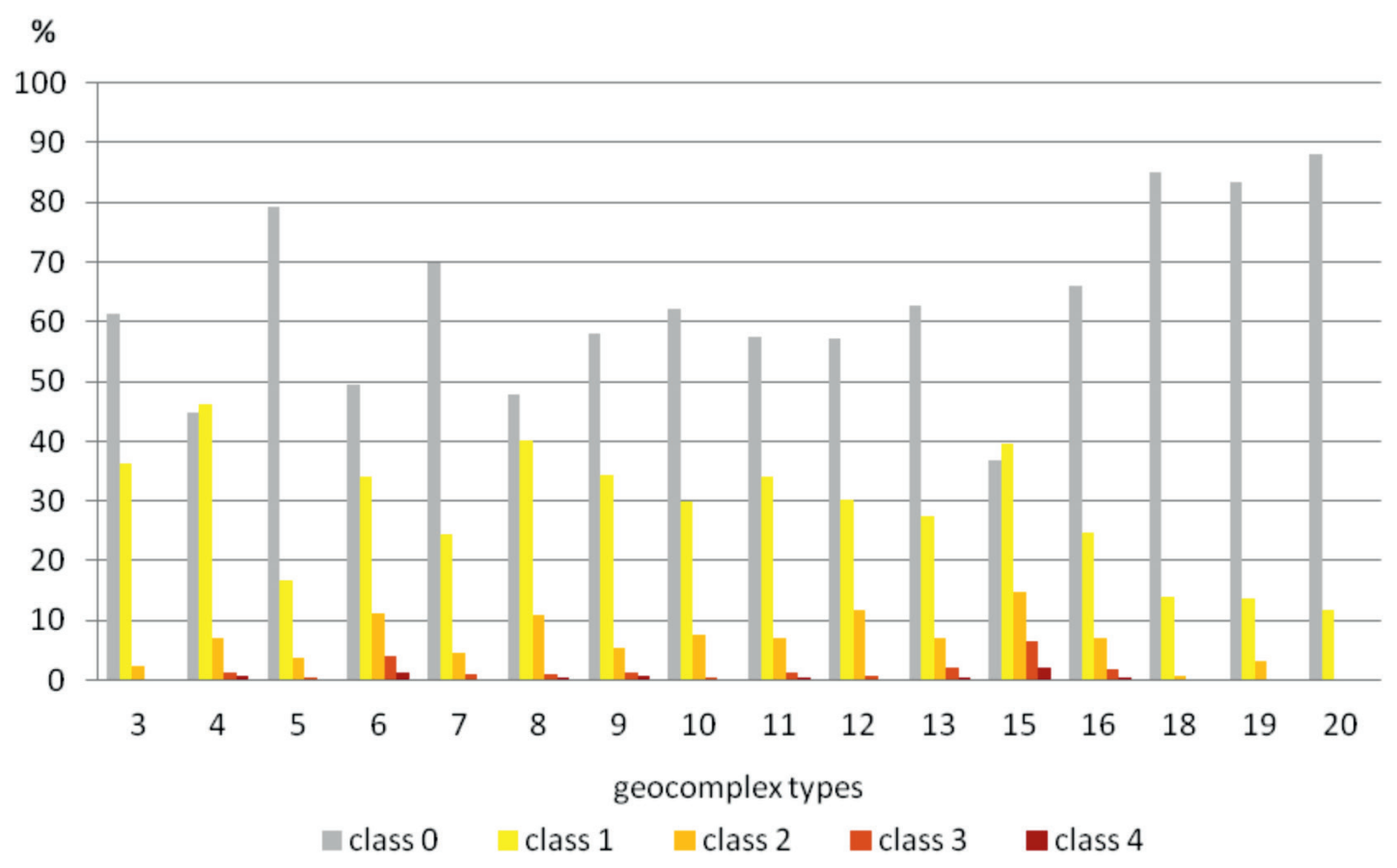

Fig. 4.24. Percentage of the area of land abandonment intensity classes in geocomplex types in the buffer zone around the Bolimów Landscape Park

Source: own elaboration 
Table 4.4. Percentage of areas of geocomplex types in land abandonment intensity classes in the buffer zone around the Bolimów Landscape Park (sorted by decreasing share in geocomplex type area)

\begin{tabular}{|c|c|c|c|c|c|c|c|c|c|}
\hline \multirow{2}{*}{$\begin{array}{l}\text { Geocom- } \\
\text { plex type }\end{array}$} & \multirow{2}{*}{\begin{tabular}{|c|}
$\begin{array}{c}\% \text { geo- } \\
\text { complex } \\
\text { type area }\end{array}$ \\
$\begin{array}{c}\text { In aban- } \\
\text { donment } \\
\text { class 0 }\end{array}$ \\
\end{tabular}} & \multirow{2}{*}{$\begin{array}{l}\text { Geocom- } \\
\text { plex type }\end{array}$} & \multirow{2}{*}{$\begin{array}{c}\begin{array}{c}\% \text { geo- } \\
\text { complex } \\
\text { type area }\end{array} \\
\begin{array}{c}\text { In aban- } \\
\text { donment } \\
\text { class } 1\end{array} \\
\end{array}$} & \multirow{2}{*}{$\begin{array}{l}\text { Geocom- } \\
\text { plex type }\end{array}$} & \multirow{2}{*}{\begin{tabular}{c|}
$\begin{array}{c}\% \text { geo- } \\
\text { complex } \\
\text { type area }\end{array}$ \\
$\begin{array}{c}\text { In aban- } \\
\text { donment } \\
\text { class 2 }\end{array}$ \\
\end{tabular}} & \multirow{2}{*}{$\begin{array}{l}\text { Geocom- } \\
\text { plex type }\end{array}$} & \multirow{2}{*}{\begin{tabular}{|c|}
$\begin{array}{c}\% \text { geo- } \\
\text { complex } \\
\text { type area }\end{array}$ \\
$\begin{array}{c}\text { In aban- } \\
\text { donment } \\
\text { class } 3\end{array}$ \\
\end{tabular}} & \multirow{2}{*}{$\begin{array}{l}\text { Geocom- } \\
\text { plex type }\end{array}$} & \multirow{2}{*}{$\begin{array}{c}\begin{array}{c}\% \text { geo- } \\
\text { complex } \\
\text { type area }\end{array} \\
\begin{array}{c}\text { In aban- } \\
\text { donment } \\
\text { class } 4\end{array}\end{array}$} \\
\hline & & & & & & & & & \\
\hline 5 & 48.05 & 5 & 26.23 & 6 & 30.86 & 6 & 49.30 & 6 & 52.63 \\
\hline 6 & 13.25 & 6 & 23.65 & 5 & 23.31 & 16 & 14.85 & 16 & 12.35 \\
\hline 16 & 12.17 & 16 & 11.84 & 16 & 13.45 & 5 & 10.03 & 9 & 10.49 \\
\hline 9 & 4.99 & 8 & 7.89 & 8 & 8.54 & 9 & 5.54 & 8 & 5.06 \\
\hline 11 & 4.06 & 9 & 7.61 & 11 & 5.18 & 13 & 5.49 & 4 & 5.02 \\
\hline 8 & 3.62 & 11 & 6.25 & 9 & 4.84 & 11 & 3.77 & 13 & 4.07 \\
\hline 13 & 3.53 & 4 & 4.85 & 13 & 4.19 & 15 & 3.37 & 15 & 3.55 \\
\hline 18 & 2.44 & 13 & 4.01 & 4 & 2.99 & 8 & 3.02 & 11 & 3.27 \\
\hline 7 & 2.23 & 7 & 2.03 & 15 & 1.71 & 4 & 2.35 & 5 & 3.16 \\
\hline 4 & 1.82 & 15 & 1.14 & 12 & 1.58 & 7 & 1.30 & 12 & 0.41 \\
\hline 19 & 0.81 & 18 & 1.04 & 7 & 1.54 & 12 & 0.47 & 18 & 0.00 \\
\hline 10 & 0.79 & 12 & 1.00 & 10 & 1.01 & 18 & 0.31 & 7 & 0.00 \\
\hline 12 & 0.73 & 3 & 1.00 & 19 & 0.33 & 10 & 0.20 & 19 & 0.00 \\
\hline 3 & 0.65 & 10 & 0.97 & 3 & 0.25 & 19 & 0.00 & 10 & 0.00 \\
\hline 20 & 0.44 & 19 & 0.34 & 18 & 0.21 & 3 & 0.00 & 3 & 0.00 \\
\hline 15 & 0.41 & 20 & 0.15 & 20 & 0.00 & 20 & 0.00 & 20 & 0.00 \\
\hline
\end{tabular}

Source: own elaboration 